\title{
Carbon-nitrogen feedbacks in the UVic ESCM
}

\author{
R. Wania ${ }^{1,5}$, K. J. Meissner ${ }^{2}$, M. Eby ${ }^{1}$, V. K. Arora ${ }^{3}$, I. Ross ${ }^{4,5}$, and A. J. Weaver ${ }^{1}$ \\ ${ }^{1}$ School of Earth and Ocean Sciences, University of Victoria, P.O. Box 3055, Victoria, BC, V8W 3V6, Canada \\ ${ }^{2}$ Climate Change Research Centre, Level 4, Mathews Building, University of New South Wales, Sydney, NSW, 2052, \\ Australia \\ ${ }^{3}$ Canadian Center for Climate Modelling and Analysis, Ocean, Earth and Atmospheric Sciences Building A203, \\ University of Victoria, 3800 Finnerty Road, Victoria BC V8P 5C2, Canada \\ ${ }^{4}$ Centre d'Ecologie Fonctionelle et Evolutive - CNRS, 1919 Route de Mende, 34293 Montpellier cedex 5, France \\ ${ }^{5}$ Lanser Strasse 30, Top A1, 6080 Igls, Austria
}

Correspondence to: R. Wania (rita@wania.net)

Received: 8 December 2011 - Published in Geosci. Model Dev. Discuss.: 10 January 2012

Revised: 17 August 2012 - Accepted: 20 August 2012 - Published: 18 September 2012

\begin{abstract}
A representation of the terrestrial nitrogen cycle is introduced into the UVic Earth System Climate Model (UVic ESCM). The UVic ESCM now contains five terrestrial carbon pools and seven terrestrial nitrogen pools: soil, litter, leaves, stem and roots for both elements and ammonium and nitrate in the soil for nitrogen. Nitrogen cycles through plant tissue, litter, soil and the mineral pools before being taken up again by the plant. Biological $\mathrm{N}_{2}$ fixation and nitrogen deposition represent external inputs to the plant-soil system while losses occur via leaching. Simulated carbon and nitrogen pools and fluxes are in the range of other models and observations. Gross primary production (GPP) for the 1990s in the $\mathrm{CN}$-coupled version is $129.6 \mathrm{Pg} \mathrm{Ca}^{-1}$ and net $\mathrm{C}$ uptake is $0.83 \mathrm{Pg} \mathrm{Ca}^{-1}$, whereas the $\mathrm{C}$-only version results in a GPP of 133.1 $\mathrm{Pg} \mathrm{Ca}^{-1}$ and a net $\mathrm{C}$ uptake of $1.57 \mathrm{Pg} \mathrm{Ca}^{-1}$. At the end of a transient experiment for the years 1800-1999, where radiative forcing is held constant but $\mathrm{CO}_{2}$ fertilisation for vegetation is permitted to occur, the $\mathrm{CN}$-coupled version shows an enhanced net $\mathrm{C}$ uptake of $1.05 \mathrm{Pg} \mathrm{Ca}^{-1}$, whereas in the experiment where $\mathrm{CO}_{2}$ is held constant and temperature is transient the land turns into a $\mathrm{C}$ source of $0.60 \mathrm{Pg} \mathrm{Ca}^{-1}$ by the 1990s. The arithmetic sum of the temperature and $\mathrm{CO}_{2}$ effects is $0.45 \mathrm{Pg} \mathrm{Ca}^{-1}, 0.38 \mathrm{Pg} \mathrm{C} \mathrm{a}^{-1}$ lower than seen in the fully forced model, suggesting a strong nonlinearity in the $\mathrm{CN}$-coupled version. Anthropogenic $\mathrm{N}$ deposition has a positive effect on Net Ecosystem Production of $0.35 \mathrm{Pg} \mathrm{Ca}^{-1}$. Overall, the UVic CN-coupled version shows similar characteristics to other $\mathrm{CN}$-coupled Earth System Models, as mea-
\end{abstract}

sured by net $\mathrm{C}$ balance and sensitivity to changes in climate, $\mathrm{CO}_{2}$ and temperature.

\section{Introduction}

There is growing evidence that the availability of nitrogen (N) in terrestrial ecosystems has an important effect on the global carbon (C) cycle (Jain et al., 2009; Gerber et al., 2010; Zaehle et al., 2010b; Bonan and Levis, 2010). Interactions between the $\mathrm{C}$ and $\mathrm{N}$ cycles range from regulation of photosynthetic rate, autotrophic respiration and heterotrophic respiration to limitation on biomass growth and litter and soil turnover rates (Lambers et al., 2008). Because of these interactions $\mathrm{N}$ can influence the sensitivity of the terrestrial C cycle to changes in temperature and atmospheric $\mathrm{CO}_{2}$ concentrations.

The sensitivity of the terrestrial carbon cycle is often expressed as the $\mathrm{C}$ sensitivity to $\mathrm{CO}_{2}$ concentration, $\beta_{\mathrm{L}}$ in $\mathrm{PgC} \mathrm{ppm}^{-1}$, and the $\mathrm{C}$ sensitivity to temperature, $\gamma_{\mathrm{L}}$ in $\mathrm{PgC} \mathrm{K}^{-1}$ (Friedlingstein et al., 2006; Plattner et al., 2008). The $\beta_{\mathrm{L}}$ value describes how vegetation responds to changes in atmospheric $\mathrm{CO}_{2}$ concentrations, whereas the $\gamma_{\mathrm{L}}$ value is mainly determined by the temperature dependent processes, namely photosynthesis, heterotrophic and autotrophic respiration rates.

C-only models estimate $\beta_{\mathrm{L}}$ to be $1.4 \pm 0.5 \mathrm{Pg} \mathrm{Cppm}^{-1}$ and $\gamma_{\mathrm{L}}$ to be $-79 \pm 45 \mathrm{PgCK}^{-1}$ (Denman et al., 2007). Models that include the interactions between the terrestrial $\mathrm{C}$ and $\mathrm{N}$ cycles show a decrease in $\beta_{\mathrm{L}}$, i.e., a suppressed $\mathrm{CO}_{2}$ 
Table 1. Pools and fluxes in the UVic CN-coupled model.

\begin{tabular}{|c|c|c|}
\hline Variable & Units & Description \\
\hline \multicolumn{3}{|l|}{ Carbon } \\
\hline$C_{\mathrm{L}}$ & $\mathrm{kgCm}^{-2}$ & Litter C pool \\
\hline$C_{\mathrm{S}}$ & $\mathrm{kgC} \mathrm{m}^{-2}$ & Soil C pool \\
\hline$C_{\text {leaf }}$ & $\mathrm{kgC} \mathrm{m}^{-2}$ & PFT-dependent leaf $\mathrm{C}$ pool \\
\hline$C_{\text {root }}$ & $\mathrm{kgC} \mathrm{m}^{-2}$ & PFT-dependent root $\mathrm{C}$ pool \\
\hline$C_{\text {wood }}$ & $\mathrm{kgCm}^{-2}$ & PFT-dependent wood C pool \\
\hline$C_{\mathrm{LF}}$ & $\mathrm{kgC} \mathrm{m}^{-2} \mathrm{a}^{-1}$ & C litterfall \\
\hline$C_{\mathrm{HUM}}$ & $\mathrm{kgC} \mathrm{m}^{-2} \mathrm{a}^{-1}$ & C humification, i.e., transfer from litter to soil \\
\hline$C_{\text {RESPL }}$ & $\mathrm{kgC} \mathrm{m}^{-2} \mathrm{a}^{-1}$ & Litter $\mathrm{C}$ respiration, i.e., transfer from litter to atmosphere \\
\hline$C_{\text {RESPS }}$ & $\mathrm{kgCm}^{-2} \mathrm{a}^{-1}$ & Soil C respiration, i.e., transfer from soil to atmosphere \\
\hline \multicolumn{3}{|c|}{$\mathrm{C} / \mathrm{N}$ ratios } \\
\hline $\mathrm{CN}_{\text {leaf }}$ & $\operatorname{kgC}(\mathrm{kg} \mathrm{N})^{-1}$ & PFT-dependent leaf $\mathrm{C} / \mathrm{N}$ ratio \\
\hline $\mathrm{CN}_{\text {root }}$ & $\operatorname{kgC}(\operatorname{kg~N})^{-1}$ & PFT-dependent root $\mathrm{C} / \mathrm{N}$ ratio \\
\hline $\mathrm{CN}_{\text {wood }}$ & $\operatorname{kgC}(\mathrm{kg} \mathrm{N})^{-1}$ & PFT-dependent wood $\mathrm{C} / \mathrm{N}$ ratio \\
\hline \multicolumn{3}{|c|}{ Organic nitrogen } \\
\hline$N_{\mathrm{L}}$ & $\mathrm{kg} \mathrm{N} \mathrm{m}^{-2}$ & Litter N pool \\
\hline$N_{\mathrm{S}}$ & $\mathrm{kg} \mathrm{N} \mathrm{m}^{-2}$ & Soil N pool \\
\hline$N_{\mathrm{V}}$ & $\mathrm{kg} \mathrm{N} \mathrm{m}^{-2}$ & Vegetation $\mathrm{N}$ pool \\
\hline$N_{\text {leaf }}$ & $\mathrm{kg} \mathrm{N} \mathrm{m}^{-2}$ & PFT-dependent leaf N pool \\
\hline$N_{\text {root }}$ & $\mathrm{kg} \mathrm{N} \mathrm{m}^{-2}$ & PFT-dependent root $\mathrm{N}$ pool \\
\hline$N_{\text {stem }}$ & $\mathrm{kg} \mathrm{N} \mathrm{m}^{-2}$ & PFT-dependent stem $\mathrm{N}$ pool \\
\hline$N_{\mathrm{LF}}$ & $\mathrm{kg} \mathrm{N} \mathrm{m}^{-2} \mathrm{a}^{-1}$ & $\mathrm{~N}$ litterfall \\
\hline$N_{\mathrm{HUM}}$ & $\mathrm{kg} \mathrm{N} \mathrm{m}^{-2} \mathrm{a}^{-1}$ & $\mathrm{~N}$ humification, i.e., transfer from litter to soil \\
\hline$N_{\mathrm{MINL}}$ & $\mathrm{kg} \mathrm{N} \mathrm{m}^{-2} \mathrm{a}^{-1}$ & Litter $\mathrm{N}$ mineralisation, i.e., transfer from litter to $\mathrm{NH}_{4}^{+}$pool \\
\hline$N_{\text {MINS }}$ & $\mathrm{kg} \mathrm{N} \mathrm{m}^{-2} \mathrm{a}^{-1}$ & Soil $\mathrm{N}$ mineralisation, i.e., transfer from soil to $\mathrm{NH}_{4}^{+}$ \\
\hline \multicolumn{3}{|c|}{ Mineral nitrogen } \\
\hline $\mathrm{NH}_{4}$ & $\mathrm{~kg} \mathrm{~N} \mathrm{~m}^{-2}$ & $\mathrm{NH}_{4}^{+}$pool \\
\hline $\mathrm{NH}_{4}^{\mathrm{DEP}}$ & $\mathrm{kg} \mathrm{N} \mathrm{m}^{-2} \mathrm{a}^{-1}$ & $\mathrm{NH}_{4}^{+}$deposition \\
\hline $\mathrm{NH}_{4}^{\mathrm{UP}}$ & $\mathrm{kg} \mathrm{N} \mathrm{m}^{-2} \mathrm{a}^{-1}$ & $\mathrm{NH}_{4}^{+}$uptake \\
\hline $\mathrm{NH}_{4}^{\mathrm{IMM}}$ & $\mathrm{kg} \mathrm{N} \mathrm{m}^{-2} \mathrm{a}^{-1}$ & $\mathrm{NH}_{4}^{+}$immobilisation \\
\hline $\mathrm{NH}_{4}^{\mathrm{LEA}}$ & $\mathrm{kg} \mathrm{N} \mathrm{m}^{-2} \mathrm{a}^{-1}$ & $\mathrm{NH}_{4}^{+}$leaching \\
\hline BNF & $\mathrm{kg} \mathrm{N} \mathrm{m}^{-2} \mathrm{a}^{-1}$ & Biological $\mathrm{N}_{2}$ fixation \\
\hline $\mathrm{NO}_{3}$ & $\mathrm{~kg} \mathrm{~N} \mathrm{~m}^{-2}$ & $\mathrm{NO}_{3}^{-}$pool \\
\hline $\mathrm{NO}_{3}^{\mathrm{DEP}}$ & $\mathrm{kg} \mathrm{N} \mathrm{m}^{-2} \mathrm{a}^{-1}$ & $\mathrm{NO}_{3}^{-}$deposition \\
\hline $\mathrm{NO}_{3}^{\mathrm{UP}}$ & $\mathrm{kg} \mathrm{N} \mathrm{m}^{-2} \mathrm{a}^{-1}$ & $\mathrm{NO}_{3}^{-}$uptake \\
\hline $\mathrm{NO}_{3}^{\mathrm{IMM}}$ & $\mathrm{kg} \mathrm{N} \mathrm{m}^{-2} \mathrm{a}^{-1}$ & $\mathrm{NO}_{3}^{-}$immobilisation \\
\hline $\mathrm{NO}_{3}^{\mathrm{LEA}}$ & $\mathrm{kg} \mathrm{N} \mathrm{m}^{-2} \mathrm{a}^{-1}$ & $\mathrm{NO}_{3}^{-}$leaching \\
\hline NIT & $\mathrm{kg} \mathrm{N} \mathrm{m}^{-2} \mathrm{a}^{-1}$ & Nitrification \\
\hline
\end{tabular}

fertilisation effect, and $\gamma_{\mathrm{L}}$ either becomes less negative or switches from being negative to being positive (Thornton et al., 2009; Sokolov et al., 2008; Bonan and Levis, 2010; Zaehle et al., 2010a), i.e., a smaller release of $C$ from the soil and vegetation pools or even an increase in these pools with increasing temperature. The overall effect of $\mathrm{C} / \mathrm{N}$ interactions on the terrestrial $\mathrm{C}$ balance is model-dependent and ranges from less $\mathrm{C}$ storage to no change in $\mathrm{C}$ storage in the future when compared to C-only models (Friedlingstein and Prentice, 2010).

Due to the growing evidence that $\mathrm{N}$ potentially has an important impact on the terrestrial $\mathrm{C}$ cycle, it is necessary to develop a suite of models that represent $\mathrm{C} / \mathrm{N}$ interactions. A good overview of the commonalities and differences between nine carbon-nitrogen cycle models can be found in Zaehle and Dalmonech (2011, Table 1). The main differences 
between models include (i) the parameterisation of the effect of $\mathrm{N}$ limitation on photosynthesis, (ii) the definition of $\mathrm{C} / \mathrm{N}$ stoichiometry (fixed or floating), (iii) how $\mathrm{N}$ is taken up by the plants, (iv) the parameterisation of denitrification, and (v) the parameterisation of $\mathrm{N}$ availability on stomatal conductance (Zaehle and Dalmonech, 2011). Even though five of the models listed in Zaehle and Dalmonech (2011) are considered "coupled carbon-nitrogen cycle climate models", the only two models that have been run in fully coupled mode in terms of carbon-climate feedbacks are Sokolov et al. (2008) and Thornton et al. (2009).

With this study, we add another model to the list of fullycoupled models: we further develop the University of Victoria Earth System Climate Model (UVic ESCM) through the incorporation of terrestrial $\mathrm{C} / \mathrm{N}$ feedback mechanisms. The UVic ESCM falls in the category of Earth System Models of Intermediate Complexity (EMIC) and is a fully coupled model described in Weaver et al. (2001). In this paper, we describe the $\mathrm{N}$ model incorporated into the UVic ESCM, we show the fundamental diagnostics of the $\mathrm{N}$ and $\mathrm{C}$ cycle and compare the results to existing models or data where appropriate.

\section{Model description and datasets}

Here we use the University of Victoria Earth System Climate Model (UVic ESCM) version 2.9 (Eby et al., 2009). It consists of a primitive equation 3-D ocean general circulation model coupled to a dynamic-thermodynamic seaice model and an energy-moisture balance model of the atmosphere with dynamical feedbacks (Weaver et al., 2001). The land surface and terrestrial vegetation components are represented by a simplified version of the Hadley Centre's MOSES land-surface scheme coupled to the dynamic vegetation model TRIFFID (Meissner et al., 2003). Land carbon fluxes are calculated within MOSES and are allocated to vegetation and soil carbon pools (Matthews et al., 2004). Ocean carbon is simulated by means of an OCMIP-type inorganic carbon-cycle model and a NPZD marine ecosystem model (Schmittner et al., 2008). Sediment processes are represented using an oxic-only model of sediment respiration (Archer, 1996).

An earlier version of the UVic ESCM (version 2.7) has undergone extensive evaluation as part of international model intercomparison projects including the Coupled Carbon Cycle Climate Model Intercomparison Project (Friedlingstein et al., 2006), the Paleoclimate Modelling Intercomparison Project (Weber et al., 2007) and the coordinated thermohaline circulation experiments (Gregory et al., 2005; Stouffer et al., 2006). The model has also been used for multi-century climate projections in support of the IPCC Fourth Assessment Report (Denman et al., 2007; Meehl et al., 2007). The most significant changes to the model since version 2.7 are the inclusion of ocean biology and sediments (Schmittner, 2005; Zickfeld et al., 2008).

Simulations include the following externally specified forcing: historical $\mathrm{CO}_{2}$ and other non- $\mathrm{CO}_{2}$ greenhouse gases (all applied as reductions in outgoing longwave radiation), stratospheric volcanic aerosols (applied as reductions in incoming shortwave radiation), tropospheric sulphate aerosols (applied as changes in local surface albedo), land use change (also applied as a surface albedo change), and solar variation due to changes in luminosity and the Earth's orbit. Historical land use change maps up to the year 1992 from Ramankutty and Foley (1999) are used to determine when to change naturally simulated vegetation (shrubs and trees) to agricultural land use (grass). Emissions from land use change are, thus, internally calculated and would not be part of any diagnosed (external) anthropogenic carbon emissions for these simulations.

For this study, carbon-nitrogen feedbacks in the terrestrial biosphere were included in the UVic-ESCM. The main changes in terms of mechanistic understanding include a prognostic representation of leaf $\mathrm{N}$ concentration, which determines the rate of photosynthesis. This implies that in the case of an $\mathrm{N}$ deficiency, leaf $\mathrm{N}$ concentrations will decrease and reduce photosynthesis rates and hence GPP. The calculation of autotrophic respiration is also affected in the new version: $\mathrm{N}$ content in leaf, root and stem - on which autotrophic respiration depends - are now simulated based on stoichiometry whereas in the C-only version the $\mathrm{N}$ content of these tissues was derived allometrically. Another change is the fact that $\mathrm{N}$ influences litter decomposition processes, leading to faster decomposition under higher soil mineral $\mathrm{N}$ concentrations. These changes are elaborated in detail below.

We keep the current structure of MOSES/TRIFFID, the vegetation model within the UVic ESCM, generally the same as described in Meissner et al. (2003). This allows us to integrate the model in a C-only mode (UVic C-only) and in a CN-coupled mode (UVic-CN) in order to evaluate the differences. The only major change to the model is the addition of a litter $\mathrm{C}$ pool as a corresponding $\mathrm{C}$ pool for the $\mathrm{N}$ litter pool.

\subsection{Carbon and nitrogen pools and fluxes}

The UVic-CN ESCM has five C pools (leaf, root, wood, litter and soil) and seven $\mathrm{N}$ pools (leaf, root, wood, litter, soil, ammonium $\left(\mathrm{NH}_{4}^{+}\right)$and nitrate $\left.\left(\mathrm{NO}_{3}^{-}\right)\right)$. The pools and the fluxes between them are shown in Fig. 1 and listed in Table 1. The concept for the $\mathrm{N}$ model is adopted from Gerber et al. (2010) with modifications in order to fit the UVic ESCM structure and with the exception of biological $\mathrm{N}_{2}$ fixation; wherever we use Gerber et al.'s approach, we mention it in the respective section below. The time steps of the new processes vary with the respective parallel processes used in the UVic ESCM. Microbial processes, leaching, photosynthesis, leaf turnover and $\mathrm{N}$ uptake are updated on an hourly basis. The 


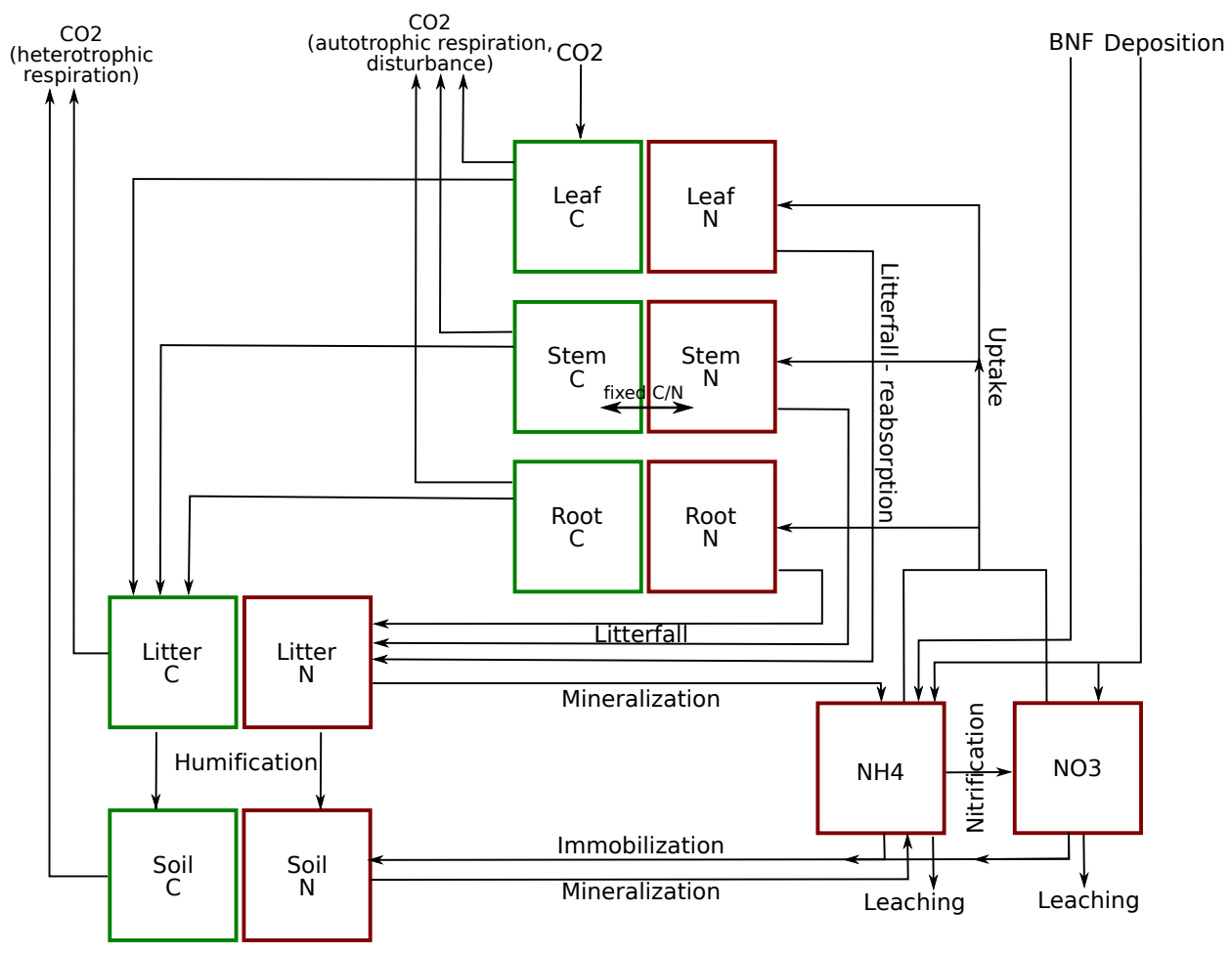

Fig. 1. Schematic representation of the carbon (green boxes) and nitrogen (red boxes) pools and fluxes in UVic-CN. The C cycle in the UVic ESCM is enhanced by adding a carbon litter pool. The nitrogen model is adapted from Gerber et al. (2010). Leaf, stem and root N content depend on the size of the $\mathrm{C}$ pools and fixed $\mathrm{C} / \mathrm{N}$ ratios. The UVic ESCM inherent leaf, root and stem turnover rates are used to calculate litterfall with the only modification that $\mathrm{N}$ in leaves is partially reabsorbed before abscission. The litterfall goes first into the litter pool, which is partially decomposed and enters the $\mathrm{NH}_{4}$ pool and part of it is humified and enters the soil $\mathrm{N}$ pool. The soil $\mathrm{N}$ pool is mineralised and adds to the $\mathrm{NH}_{4}$ pool. Ammonium is turned into $\mathrm{NO}_{3}^{-}$via nitrification. Ammonium and $\mathrm{NO}_{3}^{-}$can be immobilised by the soil pool. Both of the inorganic $\mathrm{N}$ species can be leached via runoff or taken up by plants. The plant uptake is set to meet the PFT's requirement to achieve at least the minimum $\mathrm{N}$ content.

values are accumulated over five days and fed into TRIFFID, which calculates changes to the vegetation and soil $\mathrm{C}$ and $\mathrm{N}$ pools and updates $\mathrm{C} / \mathrm{N}$ ratios.

\subsubsection{Organic pools}

Litterfall for $\mathrm{C}\left(C_{\mathrm{LF}}\right)$ is determined for each plant functional type (PFT) by the size of the carbon pools, $C_{\text {leaf }}, C_{\text {root }}$ and $C_{\text {wood }}$ and by a pool specific turnover rate, $\eta_{\text {root }}$ and $\eta_{\text {wood }}$ (Table 2):

$C_{\mathrm{LF}}=\sum_{\mathrm{PFT}} \eta_{\text {leaf }} C_{\text {leaf }}+\eta_{\mathrm{root}} C_{\mathrm{root}}+\eta_{\mathrm{wood}} C_{\mathrm{wood}}$

where $\eta_{\text {leaf }}=\eta_{\text {leaf }}^{0} f(T) f(\Theta) ; \eta_{\text {leaf }}^{0}$ is given in Table 2, $f(T)$ and $f(\Theta)$ are given in Eqs. (9) and (10).

Before plants drop their leaves, a fraction of the $\mathrm{N}$ is reabsorbed. This is taken account of by the factor $r_{\text {leaf }}$ in the calculation of litterfall for $\mathrm{N}, N_{\mathrm{LF}}$ :

$N_{\mathrm{LF}}=\sum_{\text {PFT }} \eta_{\text {leaf }} \frac{C_{\text {leaf }}}{\mathrm{CN}_{\text {leaf }}}\left(1-r_{\text {leaf }}\right)+\eta_{\text {root }} \frac{C_{\text {root }}}{\mathrm{CN}_{\text {root }}}+\eta_{\text {wood }} \frac{C_{\text {wood }}}{\mathrm{CN}_{\text {wood }}}$, where $\mathrm{CN}_{\text {leaf }}, \mathrm{CN}_{\text {root }}$ and $\mathrm{CN}_{\text {wood }}$ are the $\mathrm{C} / \mathrm{N}$ ratios of leaves, roots and wood (see Sect. 2.4.1). The $\mathrm{C} / \mathrm{N}$ ratio of litterfall, thus, differs from that of the plant source because a portion of leaf nitrogen $\left(r_{\text {leaf }}\right)$ is reabsorbed by the plant before abscission.

Litterfall $\left(C_{\mathrm{LF}}, N_{\mathrm{LF}}\right)$ is added to the litter pools $\left(C_{\mathrm{L}}, N_{\mathrm{L}}\right)$, while humification $\left(C_{\mathrm{HUM}}, N_{\mathrm{HUM}}\right)$ and litter respiration $\left(C_{\mathrm{RESPL}}\right)$ and mineralisation $\left(N_{\mathrm{MINL}}\right)$ are subtracted:

$\frac{d C_{\mathrm{L}}}{d t}=C_{\mathrm{LF}}-C_{\mathrm{HUM}}-C_{\mathrm{RESPL}}$,

$\frac{d N_{\mathrm{L}}}{d t}=N_{\mathrm{LF}}-N_{\mathrm{HUM}}-N_{\mathrm{MINL}}$.

Humification is the transfer of organic material from the litter to the soil pool (Eqs. 5 and 6), litter respiration is the decomposition of organic $\mathrm{C}$ in litter to form $\mathrm{CO}_{2}$ (Eq. 7) and litter mineralisation is the decomposition of organic $\mathrm{N}$ in litter to 
Table 2. List of PFT-dependent parameters used in UVic-CN: leaf base turnover rate $\left(\eta_{\text {leaf }}^{0}\right)$, root turnover rate ( $\left.\eta_{\text {root }}\right)$ and wood turnover rate $\left(\eta_{\text {wood }}\right)$ are all taken from the UVic ESCM. $r_{\text {leaf }}$ is the PFT-dependent retranslocation of $\mathrm{N}$ before leaf abscission and $\nu_{\text {max }}$ is the tuned maximum $\mathrm{N}$ uptake rate. Minimum and maximum $\mathrm{C} / \mathrm{N}$ ratios for leaves $\left(\mathrm{CN}_{\text {Leaf,min }}, \mathrm{CN}_{\mathrm{Leaf}, \max }\right)$ and roots $\left(\mathrm{CN}_{\mathrm{Root} \text {,min }}, \mathrm{CN}_{\mathrm{Root}, \mathrm{max}}\right)$ for each PFT are chosen as follows: $\mathrm{CN}_{\text {Leaf,min }}$ are the inverted maximum leaf $\mathrm{N}$ concentrations used in the previous UVic ESCM (Meissner et al., 2003) with the exception of the value for $\mathrm{C} 3 \mathrm{G}$ which is raised from 18 to 25 . $\mathrm{CN}_{\text {Leaf, max }}$ are allocated in order to allow a wide range of possible $\mathrm{C} / \mathrm{N}$ ratios, $\mathrm{CN}_{\text {Root,min }}$ and $\mathrm{CN}_{\text {Root,max }}$ are set to be higher than $\mathrm{CN}_{\text {Leaf,min }}$ and $\mathrm{CN}_{\text {Leaf,max }}$ (White et al., 2000). Average leaf nitrogen concentration, $n_{1}$, is used in the C-only version to calculate Rubisco activity $V_{\mathrm{c}, \max }$. BT=broad-leaved trees, NT $=$ needle-leaved trees, $\mathrm{C} 3 \mathrm{G}=\mathrm{C}_{3}$ grasses, $\mathrm{C} 4 \mathrm{G}=\mathrm{C}_{4}$ grasses, $\mathrm{SH}=$ shrubs.

\begin{tabular}{|c|c|c|c|c|c|c|}
\hline Parameter & Unit & BT & NT & C3G & C4G & $\mathrm{SH}$ \\
\hline$\eta_{\text {leaf }}^{0}$ & $a^{-1}$ & 0.25 & 0.25 & 0.25 & 0.25 & 0.25 \\
\hline$\eta_{\text {root }}$ & $a^{-1}$ & 0.25 & 0.25 & 0.25 & 0.25 & 0.25 \\
\hline$\eta_{\text {wood }}$ & $a^{-1}$ & 0.01 & 0.01 & 0.20 & 0.20 & 0.05 \\
\hline$r_{\text {leaf }}$ & - & 0.5 & 0.4 & 0.5 & 0.5 & 0.5 \\
\hline$v_{\max }$ & $10^{-9} \mathrm{~kg} \mathrm{~N}(\mathrm{~kg} \operatorname{root} \mathrm{C})^{-1} \mathrm{~s}^{-1}$ & 0.57 & 0.57 & 0.57 & 0.57 & 0.57 \\
\hline $\mathrm{CN}_{\text {Leaf,min }}$ & $\operatorname{kgC}(\operatorname{kg~N})^{-1}$ & 28 & 33 & 25 & 37 & 37 \\
\hline $\mathrm{CN}_{\text {Leaf, max }}$ & $\operatorname{kgC}(\operatorname{kg~N})^{-1}$ & 70 & 80 & 60 & 80 & 80 \\
\hline $\mathrm{CN}_{\text {Root, min }}$ & $\operatorname{kgC}(\operatorname{kg~N})^{-1}$ & 40 & 50 & 30 & 40 & 50 \\
\hline $\mathrm{CN}_{\text {Root, } \max }$ & $\operatorname{kgC}(\operatorname{kg~N})^{-1}$ & 80 & 90 & 70 & 85 & 90 \\
\hline $1 / n_{1}$ & $\operatorname{kgC}(\operatorname{kg~N})^{-1}$ & 37 & 46 & 25 & 46 & 37 \\
\hline
\end{tabular}

Table 3. List of parameters used in the UVic-CN model that are either new or have changed values.

\begin{tabular}{|c|c|c|c|c|c|}
\hline Parameter & Value & Units & Description & Used in & Source \\
\hline$\xi$ & 45 & $\mathrm{~m}^{3} \mathrm{~kg} \mathrm{~N}^{-1}$ & Modifier of litter decomposition rate & Eqs. (5)-(8) & Gerber et al. (2010) \\
\hline$\tau$ & 0.42 & - & $\begin{array}{l}\text { Fraction of decomposition transferred } \\
\text { to soil pool }\end{array}$ & Eqs. (5)-(8) & tuned $^{1}$ \\
\hline$k_{\mathrm{L}}$ & 1.419 & $a^{-1}$ & Litter turnover rate at $25^{\circ} \mathrm{C}$ & Eqs. (5)-(8) & tuned $^{1}$ \\
\hline$k_{\mathrm{S}}$ & 0.047 & $a^{-1}$ & Soil turnover rate at $25^{\circ} \mathrm{C}$ & Eqs. (12)-(14) & tuned $^{1}$ \\
\hline$k_{p, 1 / 2}$ & 0.003 & $\mathrm{~kg} \mathrm{~N} \mathrm{~m}^{-3}$ & Half-saturation constant for $\mathrm{N}$ uptake & Eqs. (19)-(20) & Gerber et al. (2010) \\
\hline$h_{\mathrm{S}}$ & 1 & $\mathrm{~m}$ & Soil depth & Eqs. (19)-(20) & UVic ESCM \\
\hline$k_{\mathrm{Nit}}$ & 51.6 & $a^{-1}$ & $\begin{array}{l}\text { Maximum nitrification rate adjusted } \\
\text { to } 25^{\circ} \mathrm{C}\end{array}$ & Eq. (21) & $\mathrm{Xu}-\mathrm{Ri}$ and Prentice (2008) \\
\hline$\epsilon$ & 0.0027 & $\operatorname{kgN}(\mathrm{kgC})^{-1}$ & Relationship between BNF and NPP & Eq. (23) & Derived from UVic-CN \\
\hline$b_{\mathrm{NH}_{4}}$ & 10 & - & Sorption/desorption buffer factor for $\mathrm{NH}_{4}$ & Table 4 & Gerber et al. (2010) \\
\hline$b_{\mathrm{NO}_{3}}$ & 1 & - & Sorption/desorption buffer factor for $\mathrm{NO}_{3}$ & Table 4 & Gerber et al. (2010) \\
\hline
\end{tabular}

${ }^{1}$ These three parameters are tuned together in order to obtain a similar value for the sum of soil C and litter C compared to the UVic ESCM v2.9 that has only a soil C pool.

form ammonium $\left(\mathrm{NH}_{4}^{+}\right)($Eq. 8):

$C_{\mathrm{HUM}}=f(T) f(\Theta) k_{\mathrm{L}} C_{\mathrm{L}}\left(1+\xi\left[N_{\min , \mathrm{av}}\right]\right) \tau$

$N_{\mathrm{HUM}}=f(T) f(\Theta) k_{\mathrm{L}} N_{\mathrm{L}}\left(1+\xi\left[N_{\min , \mathrm{av}}\right]\right) \tau$,

$C_{\mathrm{RESPL}}=f(T) f(\Theta) k_{\mathrm{L}} C_{\mathrm{L}}\left(1+\xi\left[N_{\min , \mathrm{av}}\right]\right)(1-\tau)$,

$N_{\mathrm{MINL}}=f(T) f(\Theta) k_{\mathrm{L}} N_{\mathrm{L}}\left(1+\xi\left[N_{\min , \mathrm{av}}\right]\right)(1-\tau)$.

Here the temperature dependence $f(T)$ is a function of soil temperature (Cox, 2001, Eq. 17):

$f(T)=q_{10}^{0.1\left(T_{\mathrm{s}}-25\right)}$ where $q_{10}=2.0, T_{\mathrm{s}}$ is the soil temperature in ${ }^{\circ} \mathrm{C}$ and $f(\Theta)$ is a function of soil moisture (Cox, 2001, Eq. 18):

$$
f(\Theta)=\left\{\begin{array}{lll}
1-0.8\left(S-S_{0}\right) & \text { for } \quad S>S_{0}, \\
0.2+0.5\left(\frac{S-S_{\mathrm{w}}}{S_{0}-S_{\mathrm{w}}}\right) & \text { for } \quad S_{\mathrm{W}}<S \leq S_{0}, \\
0.2 & \text { for } \quad S \leq S_{\mathrm{W}},
\end{array}\right.
$$

with $S, S_{\mathrm{w}}$ and $S_{0}$ being the soil moisture, the wilting point soil moisture and the optimum soil moisture, respectively (Cox, 2001, Eqs. 19-21). Other terms used in Eqs. (5) and (8) are a specific litter turnover rate $k_{\mathrm{L}}$ (Table 3 ), the litter pool size $\left(C_{\mathrm{L}}, N_{\mathrm{L}}\right)$ and the concentration of available, mineral $\mathrm{N}$ [ $\left.N_{\text {min,av }}\right]$ (see Table 4 for relationships between various mineral $\mathrm{N}$ pools and concentrations). The parameter $\xi$ (Table 3 ) describes the dependence of respiration and mineralisation 
Table 4. Relationship between different expressions of mineral $\mathrm{N}$ pools and concentrations. Values for $h_{\mathrm{S}}, b_{\mathrm{NH}_{4}}$ and $b_{\mathrm{NO}_{3}}$ can be found in Table 3.

\begin{tabular}{|c|c|c|c|}
\hline Variable & Derived from & Units & Description \\
\hline $\mathrm{NH}_{4}$ & & $\mathrm{~kg} \mathrm{~N} \mathrm{~m}^{-2}$ & $\mathrm{NH}_{4}^{+}$pool \\
\hline $\mathrm{NH}_{4(\text { av })}$ & $\mathrm{NH}_{4} / b_{\mathrm{NH}_{4}}$ & $\mathrm{~kg} \mathrm{~N} \mathrm{~m}^{-2}$ & Available $\mathrm{NH}_{4}^{+}$pool \\
\hline$\left[\mathrm{NH}_{4}\right]$ & $\mathrm{NH}_{4} / h_{\mathrm{S}}$ & $\mathrm{kg} \mathrm{N} \mathrm{m}^{-3}$ & $\mathrm{NH}_{4}^{+}$concentration \\
\hline$\left[\mathrm{NH}_{4(\mathrm{av})}\right]$ & {$\left[\mathrm{NH}_{4}\right] / b_{\mathrm{NH}_{4}}$} & $\mathrm{~kg} \mathrm{~N} \mathrm{~m}^{-3}$ & Available $\mathrm{NH}_{4}^{+}$concentration \\
\hline $\mathrm{NO}_{3}$ & & $\mathrm{~kg} \mathrm{~N} \mathrm{~m}^{-2}$ & $\mathrm{NO}_{3}^{-}$pool \\
\hline $\mathrm{NO}_{3(\mathrm{av})}$ & $\mathrm{NO}_{3} / b_{\mathrm{NO}_{3}}$ & $\mathrm{~kg} \mathrm{~N} \mathrm{~m}^{-2}$ & Available $\mathrm{NO}_{3}^{-}$pool \\
\hline$\left[\mathrm{NO}_{3}\right]$ & $\mathrm{NO}_{3} / h_{\mathrm{S}}$ & $\mathrm{kg} \mathrm{N} \mathrm{m}^{-3}$ & $\mathrm{NO}_{3}^{-}$concentration \\
\hline$\left[\mathrm{NO}_{3(\mathrm{av})}\right]$ & {$\left[\mathrm{NO}_{3}\right] / b_{\mathrm{NO}_{3}}$} & $\mathrm{~kg} \mathrm{~N} \mathrm{~m}^{-3}$ & Available $\mathrm{NO}_{3}^{-}$concentration \\
\hline$N_{\min (\mathrm{av})}$ & $\mathrm{NO}_{3(\mathrm{av})}+\mathrm{NH}_{4(\mathrm{av})}$ & $\mathrm{kg} \mathrm{N} \mathrm{m}^{-2}$ & Available mineral $\mathrm{N}$ pool \\
\hline$\left[N_{\min (\mathrm{av})}\right]$ & {$\left[\mathrm{NO}_{3(\mathrm{av})}\right]+\left[\mathrm{NH}_{4(\mathrm{av})}\right]$} & $\mathrm{kg} \mathrm{N} \mathrm{m}^{-3}$ & Available mineral $\mathrm{N}$ concentration \\
\hline
\end{tabular}

on available mineral nitrogen concentration and is taken from Gerber et al. (2010). The fraction $\tau$ (Table 3) defines how much of the litter is humified and transferred to the soil pool and how much is decomposed ( $\left.C_{\mathrm{RESPL}}, N_{\mathrm{MINL}}\right)$.

Humified litter material is transferred to the soil pools, $C_{\mathrm{s}}$ and $N_{\mathrm{s}}$, which are decreased by respiration $\left(C_{\mathrm{RESPS}}\right)$ in the case of $\mathrm{C}$ :

$\frac{d C_{\mathrm{S}}}{d t}=C_{\mathrm{HUM}}-C_{\mathrm{RESPS}}$,

where

$C_{\mathrm{RESPS}}=f(T) f(\Theta) k_{\mathrm{S}} C_{\mathrm{S}}$,

and by mineralisation ( $N_{\mathrm{MINS}}$ ) in case of $\mathrm{N}$. The organic $\mathrm{N}$ soil pool, $N_{\mathrm{s}}$, is further increased by the immobilisation of ammonium and nitrate $\left(\mathrm{NH}_{4}^{\mathrm{IMM}}, \mathrm{NO}_{3}^{\mathrm{IMM}}\right)$ :

$\frac{d N_{\mathrm{S}}}{d t}=N_{\mathrm{HUM}}-N_{\mathrm{MINS}}+\mathrm{NH}_{4}^{\mathrm{IMM}}+\mathrm{NO}_{3}^{\mathrm{IMM}}$,

where

$N_{\mathrm{MINS}}=f(T) f(\Theta) k_{\mathrm{S}} N_{\mathrm{S}}$.

Both soil respiration and mineralisation depend on the temperature function (Eq. 9) and moisture function (Eq. 10) mentioned above, a specific turnover rate $k_{\mathrm{S}}$ (Table 3) and the size of the pool $\left(C_{\mathrm{S}}, N_{\mathrm{S}}\right)$. The addition of the immobilisation terms to the soil $\mathrm{N}$ pool, $N_{\mathrm{S}}$, ensures a stable soil C/N ratio, and balances out any $\mathrm{N}$ deficit which may arise when the incoming material via humification has a high $\mathrm{C} / \mathrm{N}$ ratio.

The immobilisation of $\mathrm{NH}_{4}^{+}$and $\mathrm{NO}_{3}^{-}\left(\mathrm{NH}_{4}^{\mathrm{IMM}}, \mathrm{NO}_{3}^{\mathrm{IMM}}\right)$ via microorganisms occurs when soil quality decreases, i.e., the soil $\mathrm{C} / \mathrm{N}$ ratio $\left(\mathrm{CN}_{\text {soil }}\right)$ increases. In UVic- $\mathrm{CN}$, immobilisation happens when soil $\mathrm{C} / \mathrm{N}$ is greater than 13 ; consequently, soil $\mathrm{C} / \mathrm{N}$ ratios in UVic-CN are kept more or less constant. A soil $\mathrm{C} / \mathrm{N}$ ratio of 13 is in the range used by Gerber et al. (2010) and Zaehle and Friend (2010) and is also supported by observations: soil $\mathrm{C} / \mathrm{N}$ ratios were found to be
$<10$ for tropical areas and $>20$ for boreal areas (Global Soil Data Task Group, 2000) and 14.2 for tropical areas and 13.218.9 for boreal areas (Zinke et al., 1984; Esser et al., 2011). Relating immobilisation rates to the $\mathrm{C} / \mathrm{N}$ ratio is controversial as biomass and the metabolic state of microorganisms seem to be better predictors of immobilisation rates (Bengtsson et al., 2003) than soil $\mathrm{C} / \mathrm{N}$ ratios. However, microbial biomass and metabolic state are not variables that are ready to be included into a global Earth System Model. Further, we do not know whether soil $\mathrm{C} / \mathrm{N}$ ratios will change under $\mathrm{CO}_{2}$ fertilisation and higher $\mathrm{N}$ demands. Equations for immobilisation are modified from Gerber et al. (2010):

$$
\mathrm{NH}_{4}^{\mathrm{IMM}}=f(T) f(\Theta) k_{\mathrm{L}}\left(1+\xi N_{\min (\mathrm{av})}\right) \tau \frac{\mathrm{NH}_{4(\mathrm{av})}}{N_{\min (\mathrm{av})}} \frac{C_{\mathrm{L}}}{\mathrm{CN}_{\text {soil }}},
$$

$$
\mathrm{NO}_{3}^{\mathrm{IMM}}=f(T) f(\Theta) k_{\mathrm{L}}\left(1+\xi N_{\min (\mathrm{av})}\right) \tau \frac{\mathrm{NO}_{3(\mathrm{av})}}{N_{\min (\mathrm{av})}} \frac{C_{\mathrm{L}}}{\mathrm{CN}_{\text {soil }}},
$$

where $\mathrm{NH}_{4}^{\mathrm{IMM}}$ and $\mathrm{NO}_{3}^{\mathrm{IMM}}$ are in $\left(\mathrm{kg} \mathrm{N} \mathrm{m}^{-2} \mathrm{a}^{-1}\right)$, the temperature $f(T)$ and moisture function $f(\Theta)$ are given by Eqs. (9) and (10), $k_{\mathrm{L}}$ is the specific litter turnover rate $\left(\mathrm{a}^{-1}\right.$, Table 3), $\xi$ is a modifier of the $\mathrm{N}$ dependent litter decomposition rate $\left(\mathrm{m}^{3} \mathrm{~kg} \mathrm{~N}^{-1}\right.$, Table 3$), N_{\min (\text { av })}, \mathrm{NH}_{4 \text { (av) }}$ and $\mathrm{NO}_{3 \text { (av) }}$ are the total, $\mathrm{NH}_{4}^{+}$and $\mathrm{NO}_{3}^{-}$available mineral $\mathrm{N}$ pools $\left(\mathrm{kg} \mathrm{N} \mathrm{m}^{-2}\right.$, Table 4$), \tau$ is the fraction of decomposition transferred to the soil pool (Table 3 ), $C_{\mathrm{L}}$ is the litter $\mathrm{C}$ pool $\left(\mathrm{kg} \mathrm{C} \mathrm{m}^{-2}\right)$ and $\mathrm{CN}_{\text {soil }}$ is the $\mathrm{C} / \mathrm{N}$ ratio of the soil $\left(\mathrm{kgC}(\mathrm{kg} \mathrm{N})^{-1}\right)$.

\subsubsection{Mineral pools}

The UVic-CN model has two separate $\mathrm{N}$ mineral pools, ammonium $\left(\mathrm{NH}_{4}^{+}\right)$and nitrate $\left(\mathrm{NO}_{3}^{-}\right)$; for simplicity, the pools are labelled $\mathrm{NH}_{4}$ and $\mathrm{NO}_{3}$ hereafter. The rates of change of 
these two pools are given by

$$
\begin{aligned}
& \frac{d \mathrm{NH}_{4}}{d t}=N_{\mathrm{MINL}}+N_{\mathrm{MINS}}+\mathrm{BNF}+\mathrm{NH}_{4}^{\mathrm{DEP}} \\
& -\mathrm{NH}_{4}^{\mathrm{UP}}-\mathrm{NH}_{4}^{\mathrm{LEA}}-\mathrm{NH}_{4}^{\mathrm{IMM}}-\mathrm{NIT}
\end{aligned}
$$

and

$\frac{d \mathrm{NO}_{3}}{d t}=\mathrm{NIT}+\mathrm{NO}_{3}^{\mathrm{DEP}}-\mathrm{NO}_{3}^{\mathrm{UP}}-\mathrm{NO}_{3}^{\mathrm{LEA}}-\mathrm{NO}_{3}^{\mathrm{IMM}}$.

Mineralisation of $\mathrm{N}$ from litter $\left(N_{\mathrm{MINL}}\right)$ and soil pools $\left(N_{\text {MINS }}\right)$ are the autochthonous (i.e., from within the ecosystem) inputs into the $\mathrm{NH}_{4}$ pool, whereas biological nitrogen fixation (BNF; Sect. 2.2) and deposition of $\mathrm{NH}_{4}^{+}\left(\mathrm{NH}_{4}^{\mathrm{DEP}}\right.$; Sect. 2.2) are the allochthonous (i.e., from outside the ecosystem) input variables. Ammonium may be taken up by the plant $\left(\mathrm{NH}_{4}^{\mathrm{UP}}\right)$, lost by leaching $\left(\mathrm{NH}_{4}^{\mathrm{LEA}}\right)$, immobilised by microorganisms $\left(\mathrm{NH}_{4}^{\mathrm{IMM}}\right)$ or turned into $\mathrm{NO}_{3}^{-}$(nitrification, NIT). Nitrification (NIT) represents the only autochthonous flux for $\mathrm{NO}_{3}^{-}$, the only other input being the allochthonous input of atmospheric deposition of $\mathrm{NO}_{3}^{-}\left(\mathrm{NO}_{3}^{\mathrm{DEP}}\right)$. Nitrate may be taken up by plants $\left(\mathrm{NO}_{3}^{\mathrm{UP}}\right)$, leached from the soil $\left(\mathrm{NO}_{3}^{\mathrm{LEA}}\right)$ or immobilised by microorganisms $\left(\mathrm{NO}_{3}^{\mathrm{IMM}}\right)$. Equations (17) and (18) follow Gerber et al. (2010) with the modification that BNF is added to the $\mathrm{NH}_{4}$ pool, rather than being put directly into a vegetation $\mathrm{N}$ pool.

The calculation of plant uptake, $\mathrm{NH}_{4}^{\mathrm{UP}}$ and $\mathrm{NO}_{3}^{\mathrm{UP}}$ $\left(\mathrm{kg} \mathrm{N} \mathrm{m}^{-2} \mathrm{~s}^{-1}\right)$, is based on Gerber et al. (2010):

$\mathrm{NH}_{4}^{\mathrm{UP}}=\sum_{\mathrm{PFT}}\left(\frac{v_{\max } C_{\text {root }} \mathrm{NH}_{4(\mathrm{av})}}{h_{\mathrm{S}}\left(k_{p, 1 / 2}+\left[N_{\min (\mathrm{av})}\right]\right)}+\left[\mathrm{NH}_{4(\mathrm{av})}\right] Q_{\mathrm{T}}\right)$,

$\mathrm{NO}_{3}^{\mathrm{UP}}=\sum_{\mathrm{PFT}}\left(\frac{v_{\max } C_{\text {root }} \mathrm{NO}_{3(\mathrm{av})}}{h_{\mathrm{S}}\left(k_{p, 1 / 2}+\left[N_{\min (\mathrm{av})}\right]\right)}+\left[\mathrm{NO}_{3(\mathrm{av})}\right] Q_{\mathrm{T}}\right)$

and is separated into an active (first part of RHS in Eqs. 19 and 20) and a passive uptake (second part of RHS in Eqs. 19 and 20). Active plant uptake represents the part of the uptake driven by exchange of ions between the roots and the soil, i.e., for each $\mathrm{NH}_{4}^{+}$molecule taken up, a proton is exuded. Passive uptake transports $\mathrm{N}$ contained in soil water via the transpirational water stream.

Active plant uptake depends on the PFT-dependent maximum uptake rate $v_{\max }$ per unit root mass $\left(\mathrm{kgN}(\mathrm{kg} \operatorname{root} \mathrm{C})^{-1} \mathrm{~s}^{-1}\right), \quad C_{\text {root }}\left(\mathrm{kg} \mathrm{C} \mathrm{m}^{-2}\right)$, soil depth $h_{\mathrm{S}}(\mathrm{m})$, the half-saturation constant $k_{p, 1 / 2}\left(\mathrm{~kg} \mathrm{~N} \mathrm{~m}^{-3}\right)$ (see Tables 2 and 3 for values), the available ammonium $\mathrm{NH}_{4}$ (av) $\left(\mathrm{kg} \mathrm{N} \mathrm{m}^{-2}\right)$ and the total concentration of available mineral $\mathrm{N},\left[\mathrm{N}_{\min (\mathrm{av})}\right]\left(\mathrm{kg} \mathrm{N} \mathrm{m}^{-3}\right)$ (Table 4 lists the relationships between different mineral $\mathrm{N}$ pools). Passive plant uptake is expressed in terms of the PFT-dependent transpiration rate $Q_{\mathrm{T}}\left(\mathrm{m} \mathrm{s}^{-1}\right)$ and the available $\mathrm{NH}_{4}^{+}\left[\mathrm{NH}_{4(\mathrm{av})}\right]$ or $\mathrm{NO}_{3}^{-}$
$\left[\mathrm{NO}_{3(\mathrm{av})}\right]$ concentration $\left(\mathrm{kg} \mathrm{N} \mathrm{m}^{-3}\right)$. We impose lower and upper bounds for the plant uptake: the minimum plant uptake rate is set to a value to meet the minimum $\mathrm{N}$ requirements of each PFT and the maximum plant uptake rate is set so that no excess $\mathrm{N}$ is stored in the plants. The minimum $\mathrm{N}$ requirement is based on the current $\mathrm{C}$ contents in leaf, root and wood and the maximum $\mathrm{C} / \mathrm{N}$ ratios. For the maximum $\mathrm{N}$ requirement, we use the minimum $\mathrm{C} / \mathrm{N}$ ratios. Details of how the bounds are imposed are given in Sect. 2.4.1.

Nitrification (NIT) in $\mathrm{kg} \mathrm{N} \mathrm{m}^{-2} \mathrm{a}^{-1}$ follows Gerber et al. (2010):

$\mathrm{NIT}=f(T) f(\Theta) k_{\mathrm{Nit}} \mathrm{NH}_{4(\mathrm{av})}$

but uses the UVic ESCM inherent temperature $f(T)$ (Eq. 9) and moisture $f(\Theta)$ (Eq. 10) functions, a maximum nitrification rate, $k_{\mathrm{Nit}}\left(\mathrm{a}^{-1}\right.$, Table 3$)$ and the available $\mathrm{NH}_{4}^{+}$pool, $\mathrm{NH}_{4(\text { av) }}\left(\mathrm{kg} \mathrm{N} \mathrm{m}^{-2}\right.$, Table 4).

\subsection{Nitrogen input}

External nitrogen inputs consist of biological nitrogen fixation $(\mathrm{BNF})$ and atmospheric deposition of $\mathrm{NH}_{4}^{+}\left(\mathrm{NH}_{4}^{\mathrm{DEP}}\right)$ and $\mathrm{NO}_{3}^{-}\left(\mathrm{NO}_{3}^{\mathrm{DEP}}\right)$.

During model spin-up, we use the relationship between BNF and evapotranspiration (ET) based on Cleveland et al. (1999) that has been used non-transiently in C/N models of Zaehle and Friend (2010) and Yang et al. (2009):

$\mathrm{BNF}=0.1(0.0234 \mathrm{ET}-0.172) / 1000$,

where the original units are modified to $\mathrm{kg} \mathrm{N} \mathrm{m}^{-2} \mathrm{a}^{-1}$ for $\mathrm{BNF}$ and $\mathrm{mm} \mathrm{a}^{-1}$ for ET. However, using this approach for transient simulations (1800-1999) in the UVic ESCM leads to a significant reduction in NPP at the end of the 20th century due to a reduction of ET with increasing $\mathrm{CO}_{2}$ concentrations. The changes in BNF associated with increases in atmospheric $\mathrm{CO}_{2}$ concentration represent a key uncertainty in modelling future responses (Wang and Houlton, 2009). We, therefore, opt for the apparently more robust relationship used by the Community Climate Model CLM4 (Thornton et al., 2009) and relate total annual BNF to NPP. After the UVic-CN model has come to equilibrium for the year 1800 using the relationship between evapotranspiration (ET) and BNF following Eq. (22), we derive a coefficient, $\epsilon$, relating modelled BNF and net primary production (NPP):

$\mathrm{BNF}=\epsilon \mathrm{NPP}$,

where NPP is in $\mathrm{kgC} \mathrm{m}^{-2} \mathrm{a}^{-1}$ and $\epsilon$ is $2.73 \mathrm{~g} \mathrm{~N}(\mathrm{~kg} \mathrm{C})^{-1}$, giving a BNF of $180 \mathrm{Tg} \mathrm{Na}^{-1}$ for an NPP of $66 \mathrm{Pg} \mathrm{Na}^{-1}$. It must be borne in mind that using such a relationship between BNF and NPP has the potential disadvantage of increasing $\mathrm{BNF}$ in concord with $\mathrm{CO}_{2}$ fertilisation in proportion to any NPP increase. Modelling BNF is inherently difficult as it is not an easily observable flux and may depend 
on phosphorous availability and perhaps also other factors such as molybdenum (Zaehle and Dalmonech, 2011), neither of which are well known on a global scale. The variety of approaches used in $\mathrm{CN}$-cycle models to estimate $\mathrm{BNF}$ (see Table 1 in Zaehle and Dalmonech, 2011) may be taken as an indication of how little is known about modelling BNF. For this study, we tried two approaches: the first was to relate $\mathrm{BNF}$ to $\mathrm{ET}$, which led to rather strong $\mathrm{N}$ limitation over the 20th century due to the effect of increased atmospheric $\mathrm{CO}_{2}$ concentration on stomatal conductance and, therefore, on ET. The second, and also the option we chose to use, was to relate BNF to NPP as is done in the CLM-CN model (Thornton et al., 2007) and now also in the JSBACH model (Goll et al., 2012).

Deposition of $\mathrm{NH}_{3}$ and $\mathrm{NH}_{4}^{+}\left(\mathrm{NH}_{4}^{\mathrm{DEP}}\right)$ and oxidised nitrogen compounds $\left(\mathrm{NO}_{3}^{\mathrm{DEP}}\right)$ occurs in both dry and wet forms close to sources of pollution. Nitrogen deposition onto terrestrial ecosystems has increased by a factor of 3.6 since the pre-industrial period and is projected to double again between 1990 and 2050 (Galloway et al., 2004). The main centres of deposition in the early 1990s are the Eastern United States, Central Europe, India, Southeast Asia and Southeastern Brazil, which are likely to intensify and spread in the future (Galloway et al., 2004). Here, we use the global annual, natural and anthropogenic, deposition rates of these species from Dentener (2006) for the time slices of 1860, 1993 and 2050 , which are regridded from the original $5^{\circ} \times 3.75^{\circ}$ map to the UVic ESCM's resolution of $3.6^{\circ} \times 1.8^{\circ}$ and linearly interpolated between time slices in order to obtain annual deposition rates for the years 1860-1999; deposition rates for the year 1860 are used for the period 1800-1859.

\subsection{Nitrogen loss}

Mineral $\mathrm{N}$ in the UVic ESCM can be lost from the soil via leaching:

$\mathrm{NH}_{4}^{\mathrm{LEA}}=Q_{\mathrm{D}}\left[\mathrm{NH}_{4(\text { av })}\right]$

$\mathrm{NO}_{3}^{\mathrm{LEA}}=Q_{\mathrm{D}}\left[\mathrm{NO}_{3(\mathrm{av})}\right]$,

and is related to the runoff $Q_{\mathrm{D}}\left(\mathrm{m} \mathrm{a}^{-1}\right)$ and the concentration of available $\mathrm{NH}_{4}^{+}$and $\mathrm{NO}_{3}^{-}\left(\mathrm{kg} \mathrm{N} \mathrm{m}^{-3}\right)$. The available $\mathrm{N}$ depends on the sorption factor $b_{\mathrm{NH}_{4}}$ and $b_{\mathrm{NO}_{3}}$ (Table 3) and makes $\mathrm{NH}_{4}^{+}$less available for leaching than $\mathrm{NO}_{3}^{-}$due to the cation binding capacity of soils. Gaseous losses of $\mathrm{N}$ are not considered in the current model version.

\subsection{Vegetation nitrogen}

\subsubsection{Allocation of $\mathbf{N}$ to plant organs}

Nitrogen is allocated to leaves, roots and wood: the allocation of $\mathrm{N}$ to wood follows a fixed $\mathrm{C} / \mathrm{N}$ ratio of $330 \mathrm{~kg} \mathrm{C}(\mathrm{kg} \mathrm{N})^{-1}$ for broad-leaved and needle-leaved trees and for shrubs (Sitch et al., 2003). While the $\mathrm{C} / \mathrm{N}$ ratio of wood is fixed, the $\mathrm{C} / \mathrm{N}$ ratios of leaves and roots vary between a minimum and maximum value (Table 2). The change in total vegetation $\mathrm{N}\left(N_{\mathrm{V}}\right)$ is estimated by

$\frac{d N_{\mathrm{V}}}{d t}=\mathrm{NH}_{4}^{\mathrm{UP}}+\mathrm{NO}_{3}^{\mathrm{UP}}-N_{\mathrm{LF}}$,

where $\mathrm{NH}_{4}^{\mathrm{UP}}$ and $\mathrm{NO}_{3}^{\mathrm{UP}}$ are the $\mathrm{N}$ that the plant takes up in form of $\mathrm{NH}_{4}^{+}$and $\mathrm{NO}_{3}^{-}$(Eqs. 19 and 20) and $N_{\mathrm{LF}}$ is the $\mathrm{N}$ lost via litterfall (Eq. 2). Vegetation $\mathrm{N}\left(N_{\mathrm{V}}\right)$ is spread over the three plant $\mathrm{N}$ pools by first allocating $\mathrm{N}$ to wood following the fixed $\mathrm{C} / \mathrm{N}$ ratio, then allocating a minimum amount of $\mathrm{N}$ to roots to meet the maximum $\mathrm{C} / \mathrm{N}$ ratio and finally adding the remaining $\mathrm{N}$ to the leaf $\mathrm{N}$ pool. The $\mathrm{C}$ allocation scheme has not been changed in UVic-CN and the factor driving total plant $\mathrm{C}$ is the leaf area index. Carbon is allocated equally to leaves and roots and wood $\mathrm{C}$ is related to leaf area index via two allometric parameters. If there is more $\mathrm{N}$ available than needed to fill up the $N_{\text {leaf }}$ pool and $\mathrm{CN}_{\text {Leaf }}<\mathrm{CN}_{\text {Leaf,min }}$ then we set $\mathrm{CN}_{\text {Leaf }}=\mathrm{CN}_{\text {Leaf, min }}$ and any excess $\mathrm{N}$ is added to the roots. In that way, the $\mathrm{N}$ requirements for leaves are met before those for roots and only if there is sufficient $\mathrm{N}$ available do root $\mathrm{N}$ levels increase. If $\mathrm{CN}_{\text {Root }}<\mathrm{CN}_{\text {Root,min }}$ then we set $\mathrm{CN}_{\text {Root }}=\mathrm{CN}_{\text {Root,min }}$ and any excess $\mathrm{N}$ is added back to the $\mathrm{NO}_{3}^{-}$pool and subtracted from the uptake. If both $\mathrm{CN}_{\text {Leaf }}$ and $\mathrm{CN}_{\mathrm{Root}}$ are at their minimum level, the plant $\mathrm{N}$ status is at its maximum and will result in the highest modelled $V_{\mathrm{c}, \max }$. The reason for choosing this setup is to allow flexible root and leaf $\mathrm{C} / \mathrm{N}$ ratios in order to avoid immediate $\mathrm{N}$ deficiency stress when enhancing $\mathrm{C}$ acquisition rates. It has been shown that root $\mathrm{C} / \mathrm{N}$ ratios (Pendall et al., 2004; Gai-ping et al., 2006) as well as leaf $\mathrm{C} / \mathrm{N}$ ratios (Liu et al., 2005) can increase in Free Air $\mathrm{CO}_{2}$ Experiments experiments (FACE), though the interdependence between changes in root and leaf $\mathrm{C} / \mathrm{N}$ ratios still needs investigation.

\subsubsection{N availability}

Under $\mathrm{N}$ limitation in the model, i.e., when there is not enough $\mathrm{N}$ available to meet the requirement $\left(\mathrm{CN}_{\text {Leaf }}>\right.$ $\mathrm{CN}_{\text {Leaf,max }}$ ), leaching is first reduced by up to $100 \%$, then if more $\mathrm{N}$ is needed immobilisation is reduced by up to $50 \%$ and added to the plant uptake. In both cases, $\mathrm{NO}_{3}^{-}$fluxes are adjusted before $\mathrm{NH}_{4}^{+}$. Reducing leaching and immobilisation in favour of increasing uptake gives plants in the model preferential access to mineral nitrogen pools. If plant uptake requires even more $\mathrm{N}$, it is taken directly from the $\mathrm{NO}_{3}^{-}$or $\mathrm{NH}_{4}^{+}$at the same proportions as uptake happens and is added to the leaf $\mathrm{N}$ pool. This setup ensures that, given the current $\mathrm{C}$ stocks in the plant biomass, the minimal requirement for $\mathrm{N}$ to fulfil the $\mathrm{C} / \mathrm{N}$ ratios is always met. However, $\mathrm{N}$ limitation in UVic-CN starts affecting photosynthesis as soon as $\mathrm{CN}_{\text {Leaf }}>\mathrm{CN}_{\text {Leaf, min }}$. 


\subsubsection{N effect on NPP}

One of the determining factors in the rate of photosynthesis, and, therefore, NPP, is the activity of the enzyme Rubsico, which correlates well with leaf $\mathrm{N}$ concentration (e.g., Evans, 1983). This relationship is reflected in the UVic ESCM by linking the maximum rate of carboxylation by Rubisco, $V_{\mathrm{c}, \max }\left(\mathrm{mol} \mathrm{CO}_{2} \mathrm{~m}^{-2} \mathrm{~s}^{-1}\right)$ to leaf $\mathrm{N}\left(n_{1}\right)$ :

$V_{\mathrm{c}, \max }=\lambda n_{1}$.

where $n_{1}$, which is fixed for each PFT in the original equation (Cox et al., 1999, Eq. 21), is replaced by the inverse of the calculated average canopy leaf $\mathrm{C} / \mathrm{N}$ ratio $\left(\mathrm{CN}_{\text {leaf }}\right)$. The constant of proportionality $\lambda$ is 0.004 for $\mathrm{C}_{3}$ and 0.008 for $\mathrm{C}_{4}$ PFTs (Cox et al., 1999). Equation (27) means that photosynthetic activity and, therefore, plant productivity is reduced when $\mathrm{CN}_{\text {Leaf }}$ increases, but in the model it never falls to zero because of $\mathrm{N}$ limitation as $\mathrm{CN}_{\text {Leaf }}$ has a maximum value (Table 2). We opt for using the average canopy leaf $\mathrm{C} / \mathrm{N}$ ratio rather than top leaf $\mathrm{C} / \mathrm{N}$ ratio as done in Cox et al. (1999) as there is evidence that it is not the $\mathrm{C} / \mathrm{N}$ ratio of leaves that varies within a canopy, but the leaf mass area per unit area and with it the $\mathrm{N}$ mass per unit area (Hollinger, 1996). Hence, as long as $\mathrm{N}$ concentration is expressed in $\mathrm{kg} \mathrm{N}(\mathrm{kgC})^{-1}$, i.e. as the inverse of the $\mathrm{C} / \mathrm{N}$ ratio, as is done in the UVic ESCM, we can assume that there is no need to vary leaf $\mathrm{C} / \mathrm{N}$ ratios within the canopy (Thornton and Zimmermann, 2007).

Another determining factor of NPP is the rate of maintenance respiration $R_{\mathrm{m}}$ taken from the original MOSES model (Cox et al., 1999):

$R_{\mathrm{m}}=0.012 R_{\mathrm{d}}\left(S+\frac{N_{\text {root }}+N_{\text {stem }}}{N_{\text {leaf }}}\right)$,

where 0.012 is a factor to convert units of $\mathrm{mol} \mathrm{CO}_{2} \mathrm{~m}^{-2} \mathrm{~s}^{-1}$ to $\mathrm{kg} \mathrm{C} \mathrm{m}^{-2} \mathrm{~s}^{-1}$. Dark respiration $R_{\mathrm{d}}$ is linked to $V_{\mathrm{c}, \max }$ and a $Q_{10}$ of 2 via

$R_{\mathrm{d}}= \begin{cases}0.015 V_{\mathrm{c}, \max } Q_{10} & \text { for C } 3 \text { plants, } \\ 0.025 V_{\mathrm{c}, \max } Q_{10} & \text { for C4 plants. }\end{cases}$

$S$ is the soil moisture and $N_{\text {root }}, N_{\text {stem }}, N_{\text {leaf }}$ are the $\mathrm{N}$ contents in root, stem and leaf in $\mathrm{kg} \mathrm{N}(\mathrm{kgC})^{-1}$.

\subsection{Model simulations}

The model is integrated either with $\mathrm{C} / \mathrm{N}$ feedbacks switched on (labelled UVic CN-coupled mode or UVic-CN) or with both the vegetation and soil $\mathrm{C} / \mathrm{N}$ feedbacks switched off (UVic C-only mode). To switch off the soil C/N feedbacks, the term $\left(1+\xi\left[N_{\text {min,av }}\right]\right)$ is omitted from Eqs. (5)-(8) and to turn off the vegetation $\mathrm{C} / \mathrm{N}$ feedback, the leaf $\mathrm{N}$ concentrations $\left(n_{1}\right)$ given as inverse $\left(1 / n_{1}\right)$ in Table 2 are used in Eq. (27) instead of the calculated leaf $\mathrm{C} / \mathrm{N}$ ratios $\left(\mathrm{CN}_{\text {leaf }}\right)$.

Values for $n_{1}$ in the UVic C-only mode are set so that a comparable global GPP between the C-only and the CNcoupled mode is achieved $\left(R^{2}=0.8, p<0.001\right.$ for GPP at grid cell level). At steady state, vegetation $\mathrm{C}$ pools are $544 \mathrm{Pg} \mathrm{C}$ (C-only) and $651 \mathrm{Pg} \mathrm{C}$ (CN-coupled) and soil C pools are $1197 \mathrm{Pg} \mathrm{C}$ (C-only) and $1421 \mathrm{PgC}$ (CN-coupled). The spatial differences between UVic C-only and UVic-CN are the presence of greater vegetation $\mathrm{C}$ in UVic- $\mathrm{CN}$ mainly in the boreal zone (by $2-4 \mathrm{~kg} \mathrm{C} \mathrm{m}^{-2}$ ) and in some tropical areas $\left(1-4 \mathrm{~kg} \mathrm{Cm}^{-2}\right)$. The soil $\mathrm{C}$ is also higher in UVic-CN by $5-7 \mathrm{~kg} \mathrm{Cm}^{-2}$ in most of the boreal zone, by $3-6 \mathrm{~kg} \mathrm{Cm}^{-2}$ in mountainous temperate zones and by $1-3 \mathrm{~kg} \mathrm{Cm}^{-2}$ in some tropical and subtropical areas. Soil C losses in UVic-CN occur in central Europe, eastern China and central United States. A grid cell by grid cell comparison between UVic Conly and UVic-CN yields $R^{2}=0.74, p<0.001$ for soil C and $R^{2}=0.88, p<0.001$ for vegetation $\mathrm{C}$.

Both model versions are spun-up until the soil $\mathrm{C}$ pool changes by less than $0.5 \%$ per century. The models are then integrated transiently from 1800-1999 in either the $\mathrm{CN}$-coupled mode or the C-only mode. We use the usual set of forcing for the UVic ESCM (orbital parameters, solar constant, volcanic activity, sulphate concentrations, land ice cover, atmospheric $\mathrm{CO}_{2}$ concentrations, non- $\mathrm{CO}_{2}$ greenhouse gas concentrations and land use change). The only new forcing for UVic-CN is nitrogen deposition derived as described in Sect. 2.2. Nitrogen deposition affects the $\mathrm{C}$ cycle in the model only when $\mathrm{C} / \mathrm{N}$ feedbacks are switched on.

As well as fully-forced control simulations for each model version, five experiments are conducted, three with UVic-CN (E1-E3) and two with UVic C-only (E4-E5). The experiments are listed in Table 5 and are similar to other studies that used radiatively coupled/uncoupled runs (e.g., Zaehle et al., $2010 \mathrm{~b})$. The runs are transient runs for the time period 1800 1999.

Fully forced simulations are conducted for UVic-CN (FF1) and UVic C-only (FF2), in which all of the relevant forcings are used. The experiments also include radiatively coupled simulations, where the climate experiences the radiative effect of increasing atmospheric $\mathrm{CO}_{2}$ concentrations, but the vegetation experiences no $\mathrm{CO}_{2}$ fertilisation effect due to atmospheric $\mathrm{CO}_{2}$ concentrations being held constant at the 1800 level (E1 and E4) and radiatively uncoupled simulations, where the climate sees a constant $\mathrm{CO}_{2}$ concentration at 1800 levels, but the vegetation experiences the transient $\mathrm{CO}_{2}$ concentrations (E2 and E5). The third experiment for UVic-CN held $\mathrm{N}$ deposition constant at 1800 levels, whereas in E1 and E2 it is transient.

Sensitivities of the terrestrial $\mathrm{C}$ pool to $\mathrm{CO}_{2}$ concentration $\left(\beta_{\mathrm{L}}\right)$ and air temperature $\left(\gamma_{\mathrm{L}}\right)$ are calculated following Bonan and Levis (2010, Eqs. 2a and 3a):

$\beta_{\mathrm{L}}=\frac{\Delta C_{\mathrm{L}}^{(\mathrm{FF}-\text { Climate })}-\Delta C_{\mathrm{L}}^{\mathrm{FF}}}{\Delta C_{\mathrm{A}}}$

and

$\gamma_{\mathrm{L}}=\frac{\Delta C_{\mathrm{L}}^{(\mathrm{FF}-\text { Vegetation })}-\Delta C_{\mathrm{L}}^{\mathrm{FF}}}{\Delta T_{\mathrm{L}}}$, 
Table 5. Description of the UVic ESCM experiments and the forcings used. "FF" are the fully forced simulations and "E" are the experimental simulations in which the forcings are modified. In the forcing column, "FF" indicates a fully forced model, using transient $\mathrm{CO}_{2}$ concentration for the vegetation and climate and $\mathrm{N}$ deposition, "FF minus Vegetation" means that the $\mathrm{CO}_{2}$ concentration for the vegetation is held constant, "FF minus Climate" means that the $\mathrm{CO}_{2}$ concentration for the climate is held constant and "FF minus Ndep" means that the $\mathrm{N}$ deposition is held constant. "CN" indicates the use of UVic-CN and "C-only" indicates the use of UVic C-only, " $\mathrm{CO}_{2}$ for the vegetation/climate" gives the year or period that is used and Ndep gives the year or period of natural and anthropogenic $\mathrm{N}$ deposition.

\begin{tabular}{llllll}
\hline Label & Forcing & $\begin{array}{l}\text { UVic ESCM } \\
\text { version }\end{array}$ & $\begin{array}{l}\mathrm{CO}_{2} \text { for } \\
\text { for vegetation }\end{array}$ & $\begin{array}{l}\mathrm{CO}_{2} \text { for } \\
\text { for climate }\end{array}$ & Ndep \\
\hline FF1 & FF & CN & $1800-1999$ & $1800-1999$ & $1800-1999$ \\
FF2 & FF & C-only & $1800-1999$ & $1800-1999$ & - \\
E1 & FF minus Vegetation & CN & 1800 & $1800-1999$ & $1800-1999$ \\
E2 & FF minus Climate & CN & $1800-1999$ & 1800 & $1800-1999$ \\
E3 & FF minus Ndep & CN & $1800-1999$ & $1800-1999$ & 1800 \\
E4 & FF minus Vegetation & C-only & 1800 & $1800-1999$ & - \\
E5 & FF minus Climate & C-only & $1800-1999$ & 1800 & - \\
\hline
\end{tabular}

Table 6. Mean 1990s global fluxes and stocks of $\mathrm{C}$ and $\mathrm{N}$ as simulated by UVic C-only and UVic-CN driven by $\mathrm{CO}_{2}$ concentrations. The arrows indicate increases $(\nearrow$ ) or decreases $(\searrow$ ) when switching $\mathrm{C} / \mathrm{N}$ feedbacks on.

\begin{tabular}{|c|c|c|c|c|c|}
\hline Pool/Flux & UVic C-only & & UVic-CN & Other $\mathrm{CN}$ models results & Reference \\
\hline Vegetation C (Pg C) & 538.5 & $\nearrow$ & 635.4 & $\begin{array}{l}845(\mathrm{C}) \searrow 766(\mathrm{CN}) \\
647.1(\mathrm{C}) \searrow 537.0(\mathrm{CN})\end{array}$ & $\begin{array}{l}\text { Bonan and Levis (2010) } \\
\text { Zaehle et al. (2010b) }\end{array}$ \\
\hline Litter C (Pg C) & 103.9 & $\searrow$ & 81.9 & & \\
\hline Soil C (Pg C) & 1255 & $\bar{\nearrow}$ & 1471 & $\begin{array}{l}729(\mathrm{C}) \nearrow 750(\mathrm{CN}) \\
1723.1(\mathrm{C}) \searrow 1288.7(\mathrm{CN})\end{array}$ & $\begin{array}{l}\text { Bonan and Levis (2010) } \\
\text { Zaehle et al. (2010b) }\end{array}$ \\
\hline $\mathrm{GPP}\left(\mathrm{Pg} \mathrm{Ca}^{-1}\right)$ & 133.1 & $\searrow$ & 129.6 & $\begin{array}{l}167(\mathrm{C}) \searrow 163(\mathrm{CN}) \\
148.4(\mathrm{C}) \searrow 132.6(\mathrm{CN})\end{array}$ & $\begin{array}{l}\text { Bonan and Levis (2010) } \\
\text { Zaehle et al. (2010b) }\end{array}$ \\
\hline $\mathrm{NPP}\left(\mathrm{Pg} \mathrm{Ca}^{-1}\right)$ & 67.1 & $\nearrow$ & 75.2 & $\begin{array}{l}58(\mathrm{C}) \searrow 57(\mathrm{CN}) \\
65.9(\mathrm{C}) \searrow 57.5(\mathrm{CN})\end{array}$ & $\begin{array}{l}\text { Bonan and Levis (2010) } \\
\text { Zaehle et al. (2010b) }\end{array}$ \\
\hline $\operatorname{NEP}\left(\mathrm{Pg} \mathrm{Ca}^{-1}\right)$ & 1.53 & $\searrow$ & 0.83 & $2.5(\mathrm{C}) \searrow 1.8(\mathrm{CN})$ & Bonan and Levis (2010) \\
\hline NEP no land-use $\left(\mathrm{Pg} \mathrm{Ca}^{-1}\right)$ & 3.66 & $\searrow$ & 2.93 & $2.62(\mathrm{C}) \searrow 2.38(\mathrm{CN})$ & Zaehle et al. (2010b), \\
\hline Vegetation $N(\operatorname{Pg~N})$ & - & & 2.94 & 3.8 & Zaehle et al. (2010b) \\
\hline Litter N $(\operatorname{Pg} N)$ & - & & 1.00 & & \\
\hline Soil N $(\operatorname{Pg~N})$ & - & & 113.0 & 100 & Zaehle et al. (2010b) \\
\hline $\mathrm{N}$ uptake $\left(\mathrm{Tg} \mathrm{N} \mathrm{a}^{-1}\right)$ & - & & 873.2 & 1126.9 & Zaehle et al. (2010b) \\
\hline $\mathrm{N}$ loss $\left(\mathrm{Tg} \mathrm{Na}^{-1}\right)$ & - & & 222.8 & $118.1-155.3$ & Zaehle et al. (2010b) \\
\hline
\end{tabular}

where $\Delta C_{\mathrm{L}}^{\mathrm{FF}}, \Delta C_{\mathrm{L}}^{(\mathrm{FF}-\mathrm{Climate})}$ and $\Delta C_{\mathrm{L}}^{(\mathrm{FF}-\text { Vegetation })}$ are changes in land $\mathrm{C}$ in the different experiments (Table 5), $\Delta C_{\mathrm{A}}$ is the change of atmospheric $\mathrm{CO}_{2}$ concentration and $\Delta T_{\mathrm{L}}$ the change in $2 \mathrm{~m}$ land surface temperature between the period 1800-1804 and the period 1995-1999.

\section{Results and discussion}

\subsection{Nitrogen pools for 1980-1999}

The spatial distribution of $\mathrm{N}$ stocks in vegetation (Fig. 2a) shows a similar pattern to $\mathrm{C}$ stocks (Fig. 7a) with highest $\mathrm{N}$ content of $30-50 \mathrm{~g} \mathrm{~N} \mathrm{~m}^{-2}$ in forest areas. Most tropical forests fall in the $30-40 \mathrm{~g} \mathrm{~N} \mathrm{~m}^{-2}$ range, with lower values in some parts of the Amazon. Boreal zones in North America and Europe have higher $\mathrm{N}$ contents $\left(30-40 \mathrm{~g} \mathrm{~N} \mathrm{~m}^{-2}\right.$ ) than in boreal Russia. Simulated vegetation N stocks are lower compared to Gerber et al. (2010) and much lower than Xu-Ri and Prentice (2008) and Yang et al. (2009). The latter two studies simulated plant $\mathrm{N}$ contents of $150-400 \mathrm{~g} \mathrm{~N} \mathrm{~m}^{-2}$ in tropical forests, which results in vegetation $\mathrm{C} / \mathrm{N}$ ratios of 37.5133 assuming a vegetation $\mathrm{C}$ stock in tropical forests of 15$20 \mathrm{~kg} \mathrm{C} \mathrm{m}^{-2}$ (e.g., Sitch et al., 2003). The vegetation C/N ratios obtained by the UVic CN-coupled model are shown in Fig. 3 and are between 250 and 300 in tropical forests. The dominant factor for the overall $\mathrm{C} / \mathrm{N}$ ratio of the vegetation is the wood $\mathrm{C} / \mathrm{N}$ ratio as wood contributes between 70-94\% of tropical plant biomass (Vitousek et al., 1988; Malhi et al., 1999). Observed wood $\mathrm{C} / \mathrm{N}$ ratios for tropical trees vary from 95 to 730 (Martius, 1992) and any modelled vegetation $\mathrm{N}$ 
(a) Modelled Vegetation Nitrogen

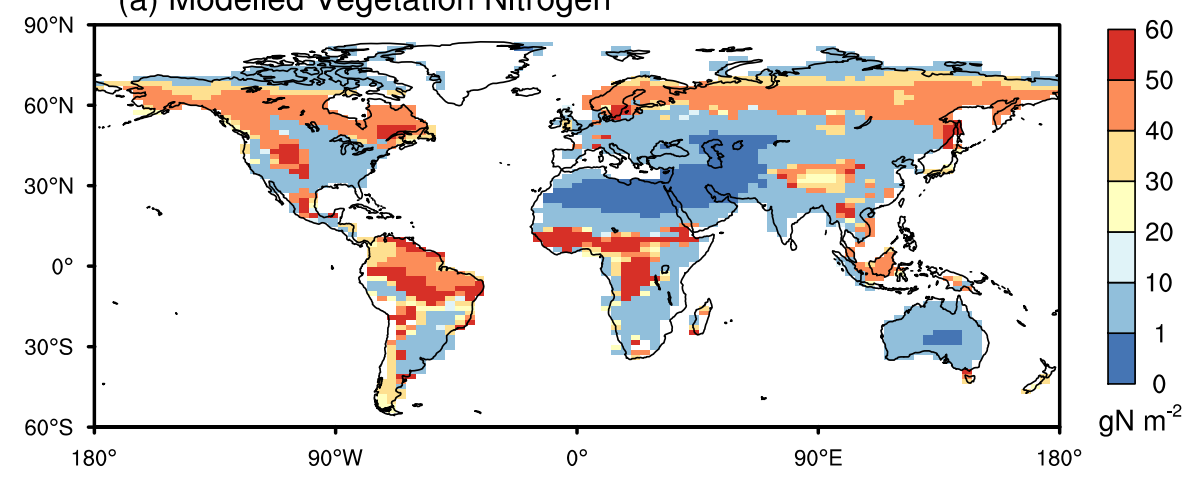

(b) Modelled Soil Nitrogen

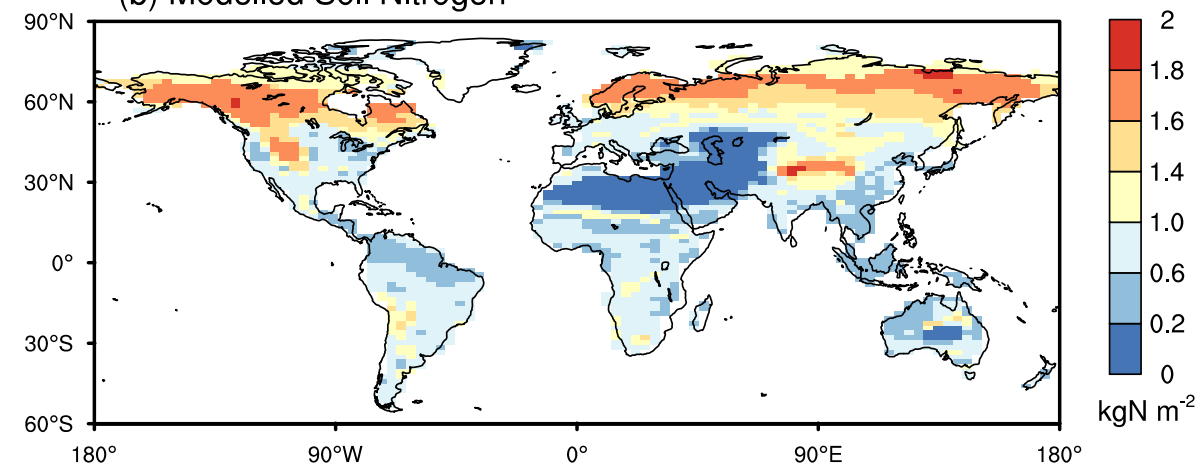

(c) IGBP-DIS Soil Nitrogen

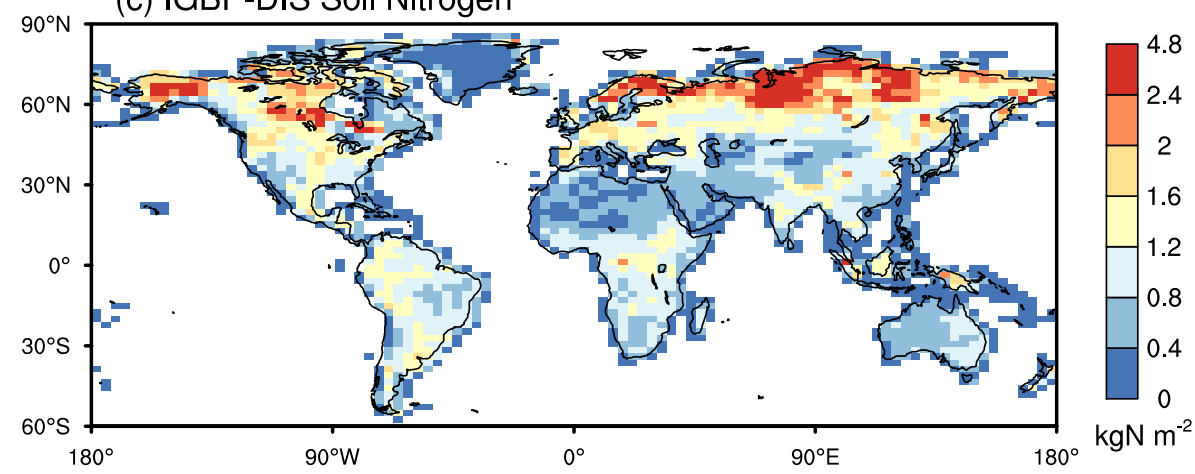

Fig. 2. Mean 1980-1999 nitrogen content in vegetation (a) and soil plus litter (b) simulated by UVic-CN and soil nitrogen content as given by the IGBP-DIS data base (Global Soil Data Task Group, 2000) (c).

content will strongly depend on the value chosen for the PFTdependent wood $\mathrm{C} / \mathrm{N}$ ratios. The global vegetation $\mathrm{N}$ pool in the UVic-CN is $2.94 \mathrm{Pg} \mathrm{N}$ close to the estimate of Zaehle et al. (2010b) (Table 6), but much lower than the estimates of Lin et al. (2000) (16 Pg N) and Yang et al. (2009) (18 Pg N). However, given that the current estimate of vegetation $\mathrm{C}$ is between 560 and $652 \mathrm{Pg} \mathrm{C}$ (Saugier and Roy, 2001), a vegetation $\mathrm{N}$ pool of $16-18 \mathrm{Pg} \mathrm{N}$ would result in an - in our opinion - unreasonably low average global vegetation $\mathrm{C} / \mathrm{N}$ ratio of 31-41. In this study, a vegetation C pool of 635.4 Pg C combined with a vegetation $\mathrm{N}$ pool of $2.94 \mathrm{Pg} \mathrm{N}$ results in a global vegetation $\mathrm{C} / \mathrm{N}$ ratio of 216 , values closer to what we expect from the fact that vegetation biomass is dominated by wood biomass with a high $\mathrm{C} / \mathrm{N}$ ratio, but higher than found in $\mathrm{O}-\mathrm{CN}(537 \mathrm{Pg} \mathrm{C}$ and $3.8 \mathrm{Pg} \mathrm{N}$ gives a $\mathrm{C} / \mathrm{N}$ ratio of 141$)$ (Table 6; note that $\mathrm{O}-\mathrm{CN}$ and $\mathrm{O}-\mathrm{C}$ stand for the $\mathrm{CN}$-coupled and the C-only versions of the ORCHIDEE model according to Zaehle and Friend (2010); Zaehle et al. (2010a,b)).

The sum of the simulated soil and litter $\mathrm{N}$ stocks are 0 $2 \mathrm{~kg} \mathrm{~N} \mathrm{~m}^{-2}$ (Fig. 2b) and, therefore, lower than the $\mathrm{N}$ values shown in the IGBP-DIS database (Fig. 2c). Since soil $\mathrm{N}$ content in the model is tied to soil $\mathrm{C}$ content via a fixed $\mathrm{C} / \mathrm{N}$ ratio, lower $\mathrm{C}$ stocks in UVic-CN (Fig. 7) lead to lower $\mathrm{N}$ stocks compared to the IGBP-DIS data (frequently over $30 \mathrm{~kg} \mathrm{C}$ in the boreal zone) (Global Soil Data Task Group, 2000). The lack of permafrost and peatlands in UVic-CN is the likely reason for the underestimation of boreal $\mathrm{C}$ stocks (Wania et al., 2009). The global soil N stocks in UVic-CN 
(a) Vegetation $\mathrm{C} / \mathrm{N}$ ratio

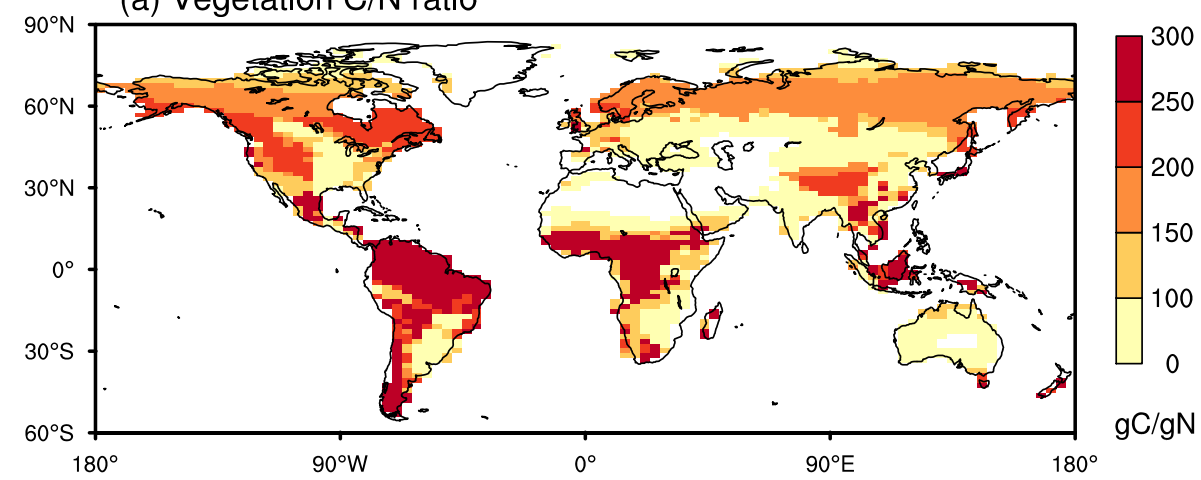

(b) Leaf $\mathrm{C} / \mathrm{N}$ ratio

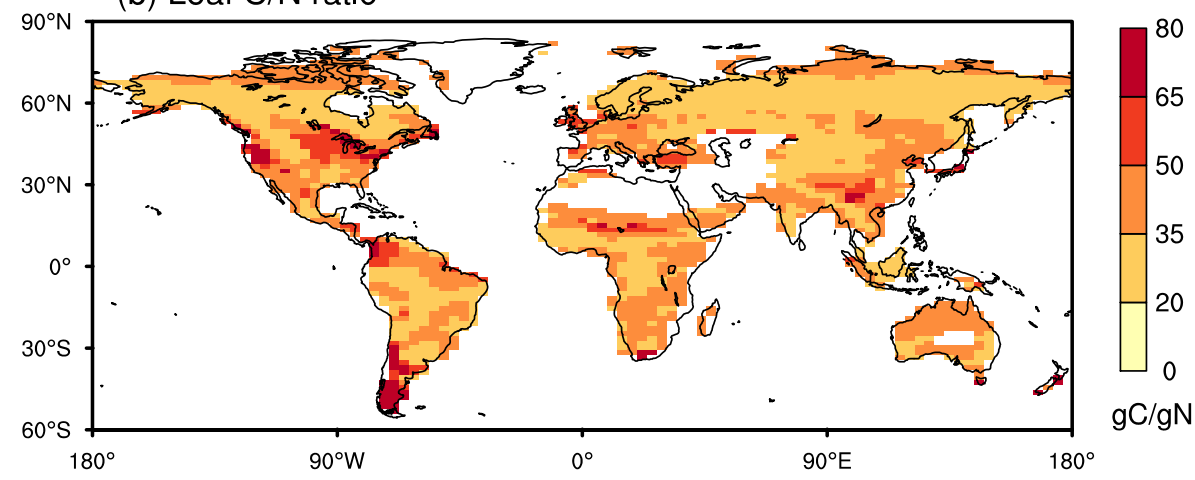

(c) Litter $\mathrm{C} / \mathrm{N}$ ratio

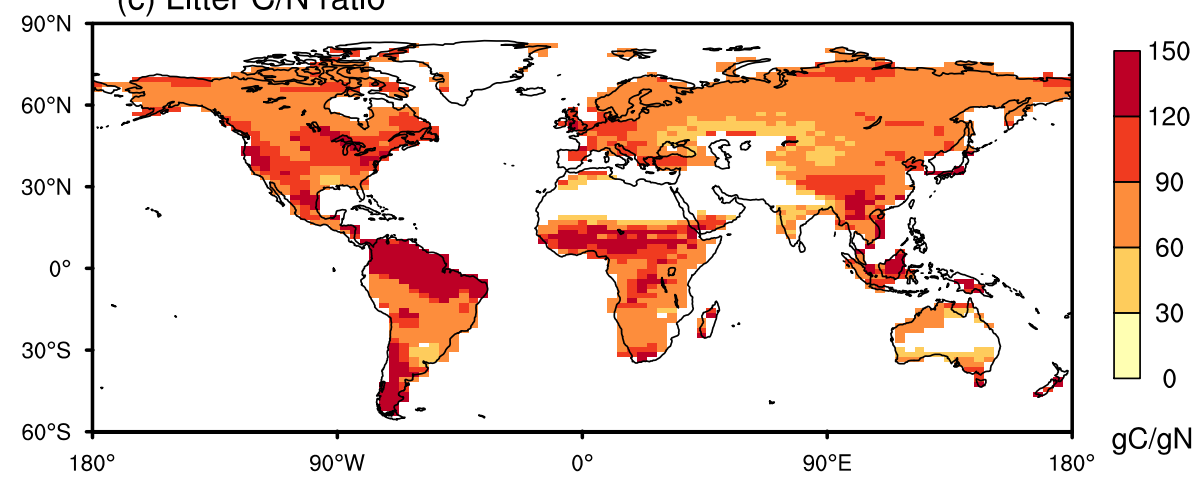

Fig. 3. Mean 1980-1999 C/N ratios of vegetation (a), leaves (b) and litter (c) simulated by UVic-CN.

are $113 \mathrm{Pg}$ N. This compares well with Zaehle et al. (2010b) $(100 \mathrm{Pg} \mathrm{N})$, Yang et al. (2009) $(65 \mathrm{Pg} \mathrm{N}$ in for the top $30 \mathrm{~cm}$ of soil) and the information from soil data bases by Post et al. (1985) and Batjes (1996) (95-140 Pg N).

In general, tropical forests show the highest simulated vegetation $\mathrm{C} / \mathrm{N}$ ratios (Fig. 3a), with some extra-tropical exceptions such as in Chile, Mexico and South Africa where both tree PFTs, broad-leaved and needle-leaved, occur. C/N ratios in temperate forests in North America are between 200 and 250 and decrease northwards to $150-200 \mathrm{~kg} \mathrm{C}(\mathrm{kg} \mathrm{N})^{-1}$, a value range also seen for the Eurasian boreal zone. In general, simulated vegetation $\mathrm{C} / \mathrm{N}$ ratios are lower in areas where the percentage of leaf and root biomass is relatively high. In boreal areas simulated leaves and roots constitute about $10 \%$ of total biomass, whereas in some tropical regions leaves and roots constitute only $3 \%$ of the total biomass compared to observed $4.5 \%$ in northern conifer ecosystems and $1.9 \%$ in tropical closed forests (Vitousek et al., 1988). Since leaves and roots are richer in $\mathrm{N}$ than wood, areas with high percentages of leaf and root biomass show lower $\mathrm{C} / \mathrm{N}$ ratios (temperate and boreal forests) than areas with low percentages of leaf and root biomass (tropical forests). Litter $\mathrm{C} / \mathrm{N}$ ratios follow the vegetation $\mathrm{C} / \mathrm{N}$ ratio closely (Fig. 3c) and we find some correspondence to observed values: comparing values from UVic-CN with those from White et al. (2000), all values in $\mathrm{kgC}(\mathrm{kg} \mathrm{N})^{-1} \pm$ standard deviation, we find $78 \pm 13$ vs. $93 \pm 28$ for evergreen needleleaved forests, $87 \pm 19$ vs. $75 \pm 37$ for shrubs and $67 \pm 18$ vs. $45 \pm 11$ for grass. 

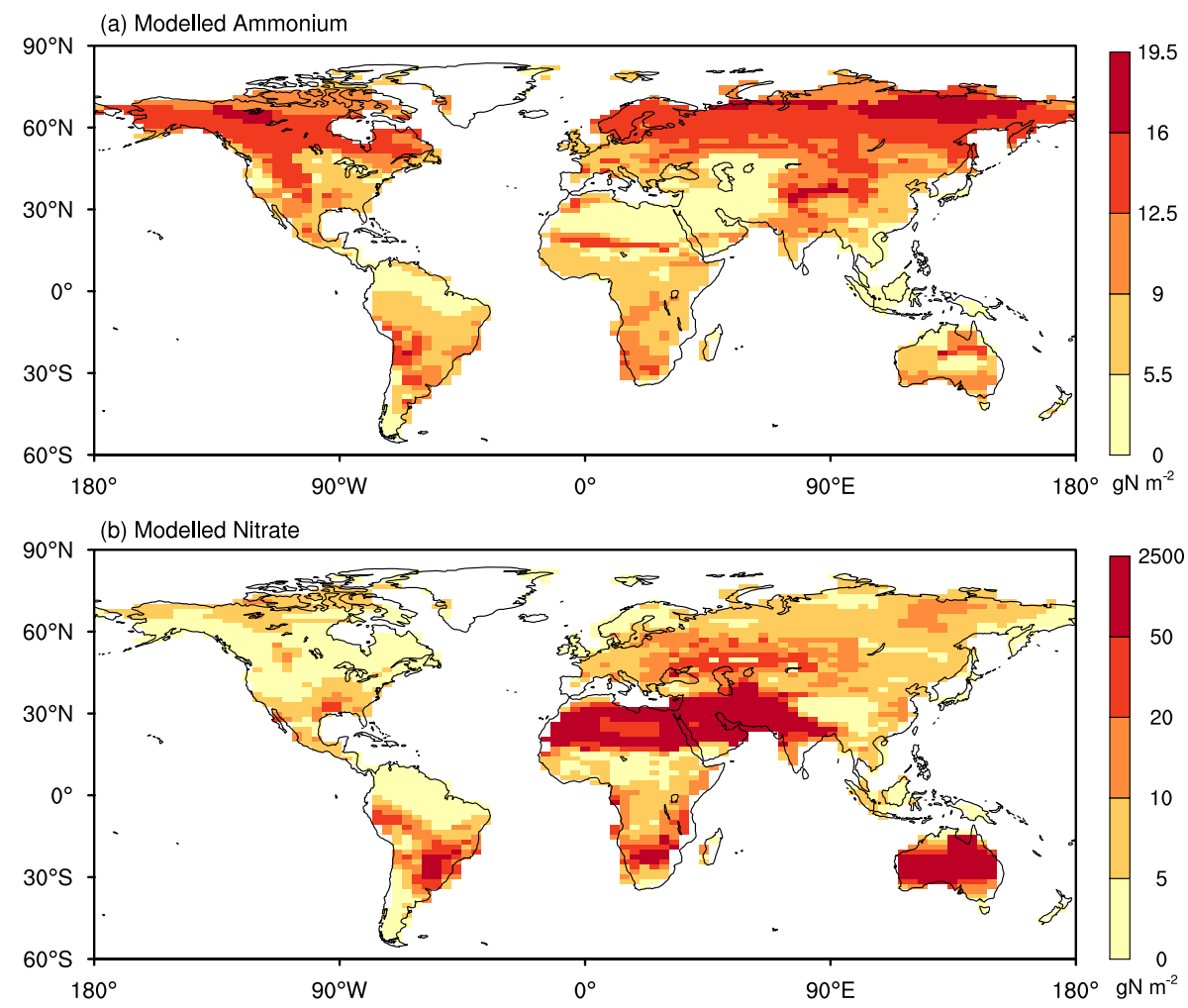

Fig. 4. Mean 1980-1999 ammonium (a) and nitrate (b) pools in the soil simulated by UVic-CN.

Ammonium and nitrate pools (Fig. 4) show some similarity to the results shown in Xu-Ri and Prentice (2008, Figs. 12 and 13). Both Xu-Ri and Prentice (2008) and UVic-CN simulate higher $\mathrm{NH}_{4}^{+}$in colder regions and higher $\mathrm{NO}_{3}^{-}$in desert areas. High $\mathrm{NO}_{3}^{-}$concentrations have been observed in the sub-soils of some deserts (Walvoord et al., 2003). The reason for the high concentrations of $\mathrm{NO}_{3}^{-}$in desert areas in UVic-CN is the small but constant input of atmospheric $\mathrm{NO}_{3}^{-}$ which accumulates over time due to limited output such as vegetation uptake and leaching. The higher $\mathrm{NH}_{4}^{+}$concentrations in colder regions can be explained by lower leaching and nitrification rates. The global soil $\mathrm{NO}_{3}^{-}$and $\mathrm{NH}_{4}^{+}$ pools seem to be poorly constrained by data and are simulated by our study to be $14.8 \mathrm{Pg} \mathrm{N}$ and $1.2 \mathrm{Pg} \mathrm{N}$, respectively, which is higher than $\mathrm{Xu}-\mathrm{Ri}$ and Prentice (2008)'s estimates of $0.58 \mathrm{Pg} \mathrm{N}$ and $0.36 \mathrm{Pg} \mathrm{N}$ for $\mathrm{NO}_{3}^{-}$and $\mathrm{NH}_{4}^{+}$, close to the estimate of $17 \mathrm{Pg} \mathrm{N}$ by Esser et al. (2011) and lower than the $25 \mathrm{Pg} \mathrm{N}$ of total mineral $\mathrm{N}$ estimated by Lin et al. (2000). In the absence of reliable observation-based estimates of $\mathrm{NO}_{3}^{-}$ in desert areas and better global constraints on mineral $\mathrm{N}$ in soils, the evaluation of simulated $\mathrm{N}$ pools from any model remains difficult.

\subsection{Nitrogen fluxes for 1980-1999}

Global annual rates of plant $\mathrm{N}$ uptake $\left(873.2 \mathrm{Tg} \mathrm{Na}^{-1}\right)$ are lower than estimates from other models (1002 to $1126 \mathrm{Tg} \mathrm{N} \mathrm{a}^{-1}$ ) (Xu-Ri and Prentice, 2008; Yang et al., 2009; Zaehle et al., 2010b). As discussed above, the vegetation $\mathrm{C} / \mathrm{N}$ ratios in UVic- $\mathrm{CN}$ are higher compared to other models, which reduces the demand for plant $\mathrm{N}$ uptake and explains the lower uptake rates. Generally, uptake rates in UVic-CN range from 3-9 $\mathrm{g} \mathrm{N} \mathrm{m}^{-2} \mathrm{a}^{-1}$ in temperate and boreal regions to $3-15 \mathrm{~g} \mathrm{~N} \mathrm{~m}^{-2} \mathrm{a}^{-1}$ in tropical regions (Fig. 5a). Higher values of $15-23 \mathrm{~g} \mathrm{~N} \mathrm{~m}^{-2} \mathrm{a}^{-1}$ can be found in tropical grasslands (in this case, in sub-Saharan Africa, India, Southern Brazil and Northern Australia). Nitrogen uptake rates in the O-CN model are estimated to be 4,8 and $13 \mathrm{~g} \mathrm{~N} \mathrm{~m}^{-2} \mathrm{a}^{-1}$ in boreal, temperate broadleaved and tropical regions respectively with maximal uptake rates of $30 \mathrm{~g} \mathrm{~N} \mathrm{~m}^{-2} \mathrm{a}^{-1}$ found in grasslands (Zaehle et al., 2010b).

The spatial distribution of leaching is similar to that of runoff with highest values in the tropics and negligible values in drier and colder regions (Fig. 5b). Global annual $\mathrm{N}$ losses via leaching total $222 \mathrm{Tg} \mathrm{Na}^{-1}$ and represent $84 \%$ of $\mathrm{N}$ input. UVic-CN currently lacks algorithms to simulate denitrification processes, which are estimated to contribute naturally approximately $35 \%$ to global $\mathrm{N}$ losses from land (excluding river emissions) 

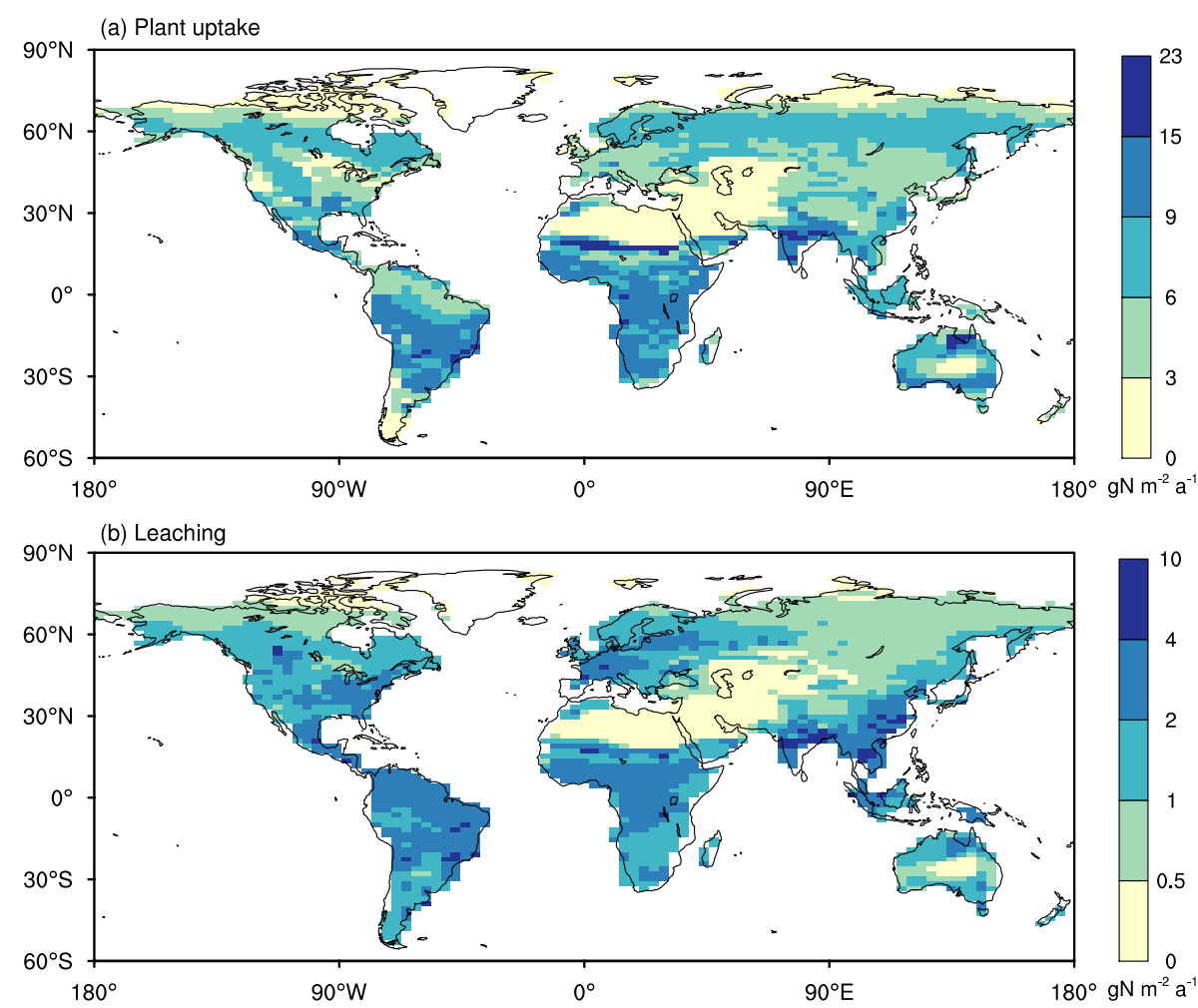

Fig. 5. Mean 1980-1999 plant uptake (a) and leaching (b) of nitrogen simulated by UVic-CN.

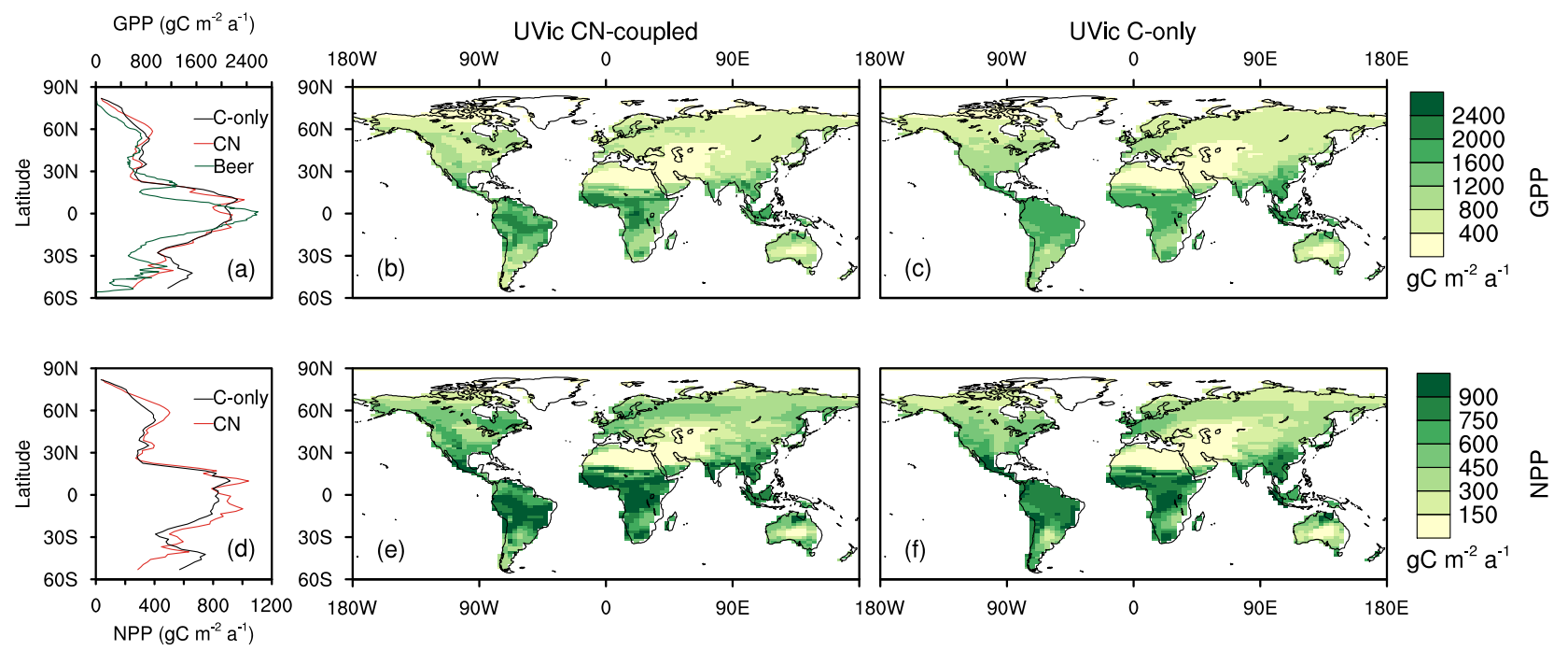

Fig. 6. Mean 1980-1999 gross primary production (GPP) (top row) and net primary production (NPP) (bottom row) for UVic C-only and UVic-CN. The line graphs on the left hand side are zonal averages of the UVic C-only (black), the UVic-CN (solid red) data shown in the maps per $1.8^{\circ}$ latitude and the median data-driven zonally averaged GPP values taken from Beer et al. (2010) (green).

(Bai et al., 2012; Gruber and Galloway, 2008). There are two reasons for not including denitrification in this first version of UVic-CN: (i) we followed the approach by Gerber et al. (2010), who also omitted denitrification and (ii) while denitrification is a microbial process that depends on small-scale environmental conditions, the UVic ESCM has a coarse resolution of $3.6^{\circ} \times 1.8^{\circ}$. Including such a smallscale process into a coarse resolution model would therefore add a significant uncertainty. Zaehle and Dalmonech (2011) discuss the difficulty of modelling denitrification in global 

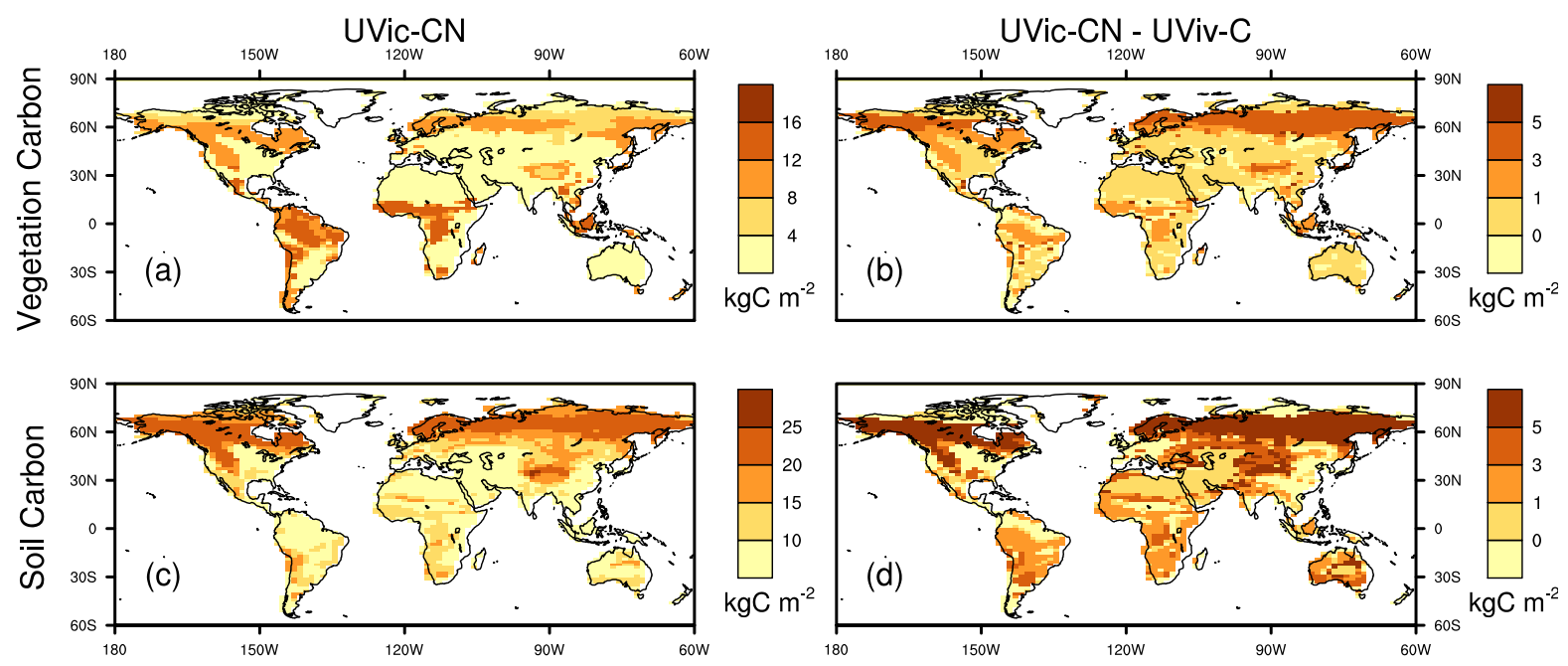

Fig. 7. Mean 1980-1999 carbon content in vegetation (a) and soil plus litter (c) for the UVic-CN simulation (left) and the difference between UVic-CN and UVic C-only (right) for vegetation (b) and soil plus litter (d).

(a) GPP

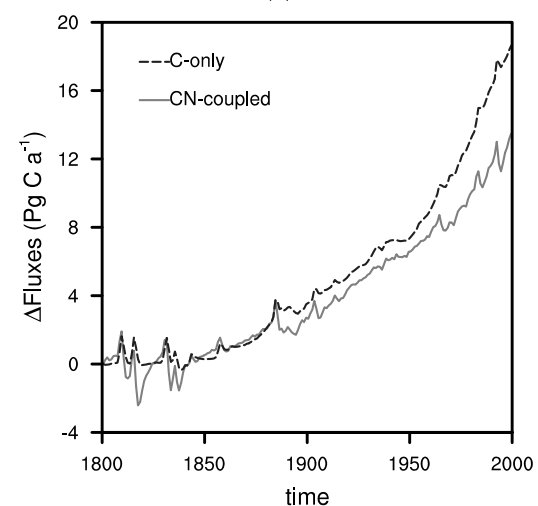

(d) Vegetation C

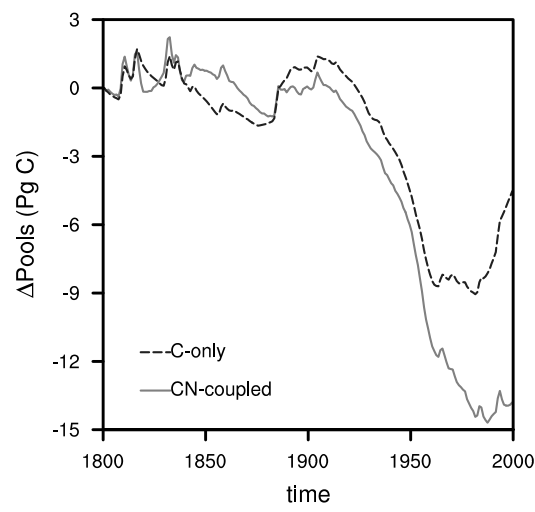

(b) NPP

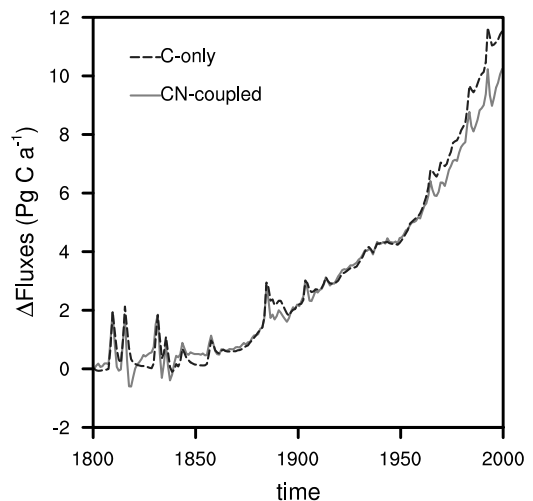

(e) Litter + Soil C

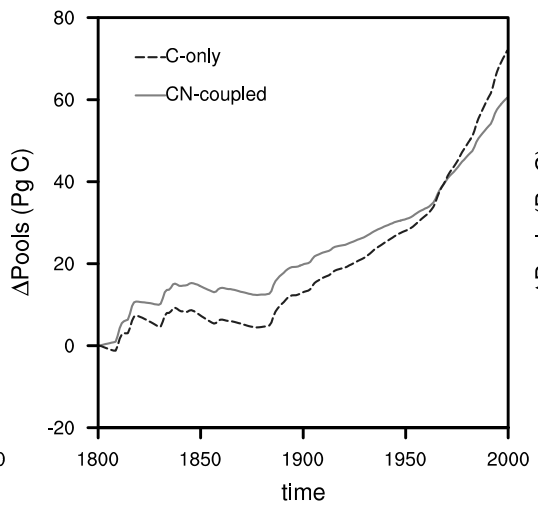

(c) HR

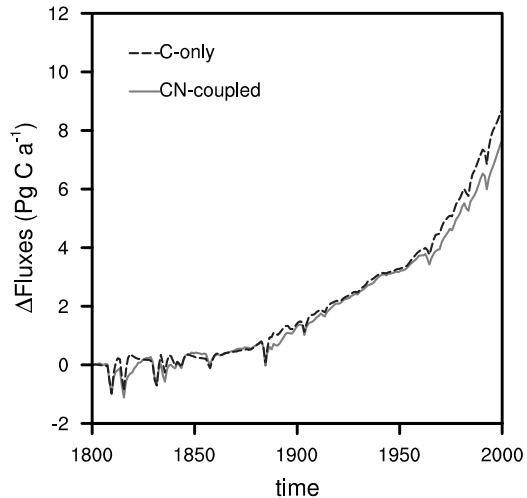

(f) Total Land C

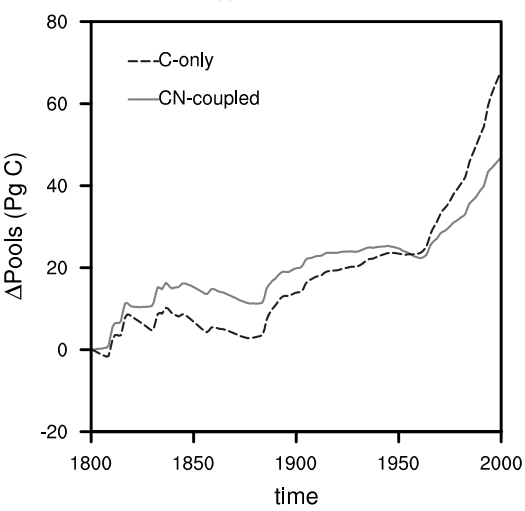

Fig. 8. Changes of carbon fluxes from 1800 to 2000: (a) GPP=gross primary production, (b) NPP= net primary production and (c) $\mathrm{HR}=$ heterotrophic respiration and changes of carbon pools (d) vegetation, (e) litter plus soil and (d) total, i.e., the sum of (d) and (e) for UVic-CN (grey solid line) and UVic C-only (black dashed line) simulations. 
models and identify denitrification as both the most uncertain and most poorly constrained part of $\mathrm{C} / \mathrm{N}$ cycle models. Both leaching and denitrification depend, amongst other factors, on the concentration of nitrate in the soils. Since denitrification is omitted in our model, it can be assumed that nitrate concentrations in the current version are slightly overestimated. However, if nitrate concentrations rise in the model, leaching rates will consequently increase and more or less counterbalance the lack of denitrification. Therefore, due to the lack of gaseous $\mathrm{N}$ losses in the UVic-CN, the model's leaching flux needs to be compared to the sum of leaching and gaseous fluxes in other models. Zaehle et al. (2010b) estimate total $\mathrm{N}$ losses of $118.1-155.3 \mathrm{Tg} \mathrm{N} \mathrm{a}^{-1}$ in the O-CN model and Gruber and Galloway (2008) estimate the rate of $\mathrm{N}$ losses via leaching and gaseous losses to be $308 \mathrm{Tg} \mathrm{N} \mathrm{a}^{-1}$ without and $397 \mathrm{Tg} \mathrm{N} \mathrm{a}^{-1}$ with anthropogenic perturbations.

\subsection{Effect of $\mathbf{C} / \mathbf{N}$ feedbacks on carbon pools and fluxes}

Before integrating the UVic model versions transiently, experiments are used to re-adjust the leaf nitrogen values $\left(n_{1}\right)$ used in UVic C-only in Eq. (27) in order to achieve a comparable annual gross primary productivity (GPP) in both model versions for the pre-industrial simulations (Table 6). The resulting GPP values for $1800-1849$ are $115.8 \mathrm{Pg} \mathrm{Ca}^{-1}$ for the $\mathrm{C}$-only and 117.2 $\mathrm{Pg} \mathrm{Ca}^{-1}$ for UVic-CN. Despite the fact that GPP of UVic C-only is slightly lower at the beginning of the transient simulation, by the 1990s the GPP of UVic Conly is $133.1 \mathrm{Pg} \mathrm{Ca}^{-1}$ and, therefore, higher than in UVic$\mathrm{CN}\left(129.6 \mathrm{Pg} \mathrm{Ca}^{-1}\right)$ (Table 6). This indicates that $\mathrm{N}$ availability has already led to the limitation of GPP in UVic-CN by the end of the 20th century. This N limitation of GPP around the end of the 20th century is also found in the CLM4 (Bonan and Levis, 2010) and O-CN (Zaehle et al., 2010b) models.

Despite similar GPP between UVic C-only and UVic-CN for the pre-industrial period, NPP differs between the two versions: $56.4 \mathrm{Pg} \mathrm{Ca}^{-1}$ (C-only) versus $66.0 \mathrm{Pg} \mathrm{Ca}^{-1}(\mathrm{CN})$ for the $1800-1849$ period and $67.1 \mathrm{Pg} \mathrm{Ca}^{-1}$ (C-only) versus 75.2 $\mathrm{Pg} \mathrm{Ca}^{-1}(\mathrm{CN})$ for the 1990s. The reason for the difference in NPP values is the dependence of autotrophic respiration on $\mathrm{N}$ content in leaf, root and stem in the UVic model (Eq. 28), which follows the original MOSES/TRIFFID version (Cox et al., 1999).

In UVic C-only, as in the original MOSES/TRIFFID code, $\mathrm{N}$ contents in root and stem are calculated in relation to the leaf $\mathrm{N}$ content (Cox et al., 1999, Eqs. 31-33), but not in relation to wood $\mathrm{C}$ content, which can result in unrealistically high wood $\mathrm{C} / \mathrm{N}$ ratios. In UVic- $\mathrm{CN}$, wood $\mathrm{C} / \mathrm{N}$ ratios are fixed at $330 \mathrm{kgC}(\mathrm{kg} \mathrm{N})^{-1}$, which leads to higher wood $\mathrm{N}$ content. Further, leaf $\mathrm{N}$ contents vary between a lower and an upper boundary modulated by the actual availability of $\mathrm{N}$ to the plant, which leads to higher leaf $\mathrm{N}$ levels in UVic-CN compared to the UVic C-only. From Eq. (28) it can be seen that increasing stem $\mathrm{N}\left(N_{\text {stem }}\right)$ increases maintenance respiration, $R_{\mathrm{m}}$, and increasing leaf $\mathrm{N}\left(N_{\text {leaf }}\right)$ decreases $R_{\mathrm{m}}$. The overall effect of changing $\left(N_{\text {stem }}\right)$ and $\left(N_{\text {leaf }}\right)$ in UVic-CN is that $R_{\mathrm{m}}$ is reduced by approximately one third, which reduces total autotrophic respiration and, therefore, increases NPP.

The effect of the reduction of autotrophic respiration can also be seen in the zonal averaged NPP values in Fig. 6d. NPP in UVic-CN is higher than in UVic C-only at latitudes where the vegetation is dominated by trees, i.e., the tropics and boreal regions (not considering the $30^{\circ} \mathrm{S}$ to $60^{\circ} \mathrm{S}$ latitudinal band, where GPP differs between the Conly and the $\mathrm{CN}$-coupled mode, but where the land mass is very low). Although NPP in UVic-CN is higher than in CLM4 and O-CN (Bonan and Levis, 2010; Zaehle et al., 2010b), it is still within the range of other model estimates of 55.4-83.8 $\mathrm{Pg} \mathrm{Ca}^{-1}$ (Arora and Matthews, 2009). The ratio of NPP:GPP increased from 0.50 to 0.58 from when introducing $\mathrm{C} / \mathrm{N}$ feedbacks into the UVic ESCM and is difficult to reconcile with current ecological knowledge. CLM4-CN has an NPP:GPP ratio of 0.35 (Bonan and Levis, 2010) and O-CN of 0.43 (Zaehle et al., 2010b). A data-based analysis suggests NPP:GPP ratios of 0.24 in the tropics and 0.53 in temperate regions (Luyssaert et al., 2007). This points towards the necessity of re-visiting the autotrophic respiration calculation in MOSES/TRIFFID, which strongly influenced the NPP:GPP ratio in UVic-CN.

The increase in NPP in UVic C-only from 1800 to 1999 is $19 \%$, compared to $12 \%$ in UVic-CN. It is still uncertain how much of an $\mathrm{CO}_{2}$ fertilisation effect we can expect. Early results from Free Air $\mathrm{CO}_{2}$ Enrichment (FACE) experiments suggest an increase in productivity of temperate forest ecosystems by $23 \pm 2 \%$ for approximately $550 \mathrm{ppmv} \mathrm{CO}_{2}$ (Norby et al., 2005), which is also reproduced in a modelling study (Hickler et al., 2008). However, the modelling response to $\mathrm{CO}_{2}$ fertilisation varied from an enhancement by $15.1 \%$ for boreal forests to $35.1 \%$ for tropical forests (Hickler et al., 2008). More recent results from one of the FACE experiments show that the initial increase of NPP of deciduous sweetgum trees due to enhanced $\mathrm{CO}_{2}$ wore off after an initial 4-5 yr period and dropped from an enhancement effect of $24 \%$ in 2001-2003 to $9 \%$ in 2009, which is hypothesised to be caused by N-limitation (Norby et al., 2010; Garten Jr. et al., 2011), supporting the $\mathrm{N}$ limitation seen in models. However, the decrease in NPP in the deciduous sweetgum is not reproduced in the evergreen Pinus taeda at the Duke FACE experimental site, which showed a continuous enhancement of NPP by 22-30\% (McCarthy et al., 2010).

Over the 1980-1990 period, the zonally averaged GPP values from both model versions are comparable (Fig. 6). The main difference between the two model versions arises between the latitudes $30^{\circ} \mathrm{S}$ and $60^{\circ} \mathrm{S}$. UVic-CN simulates lower average GPP values for this part of the Southern Hemisphere than UVic C-only, which fit the observed, dataderived median GPP values from Beer et al. (2010) better. 

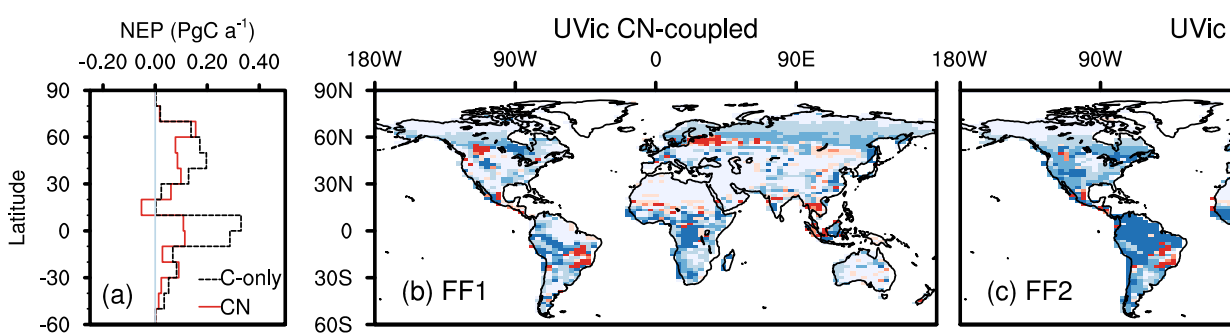

UVic C-only
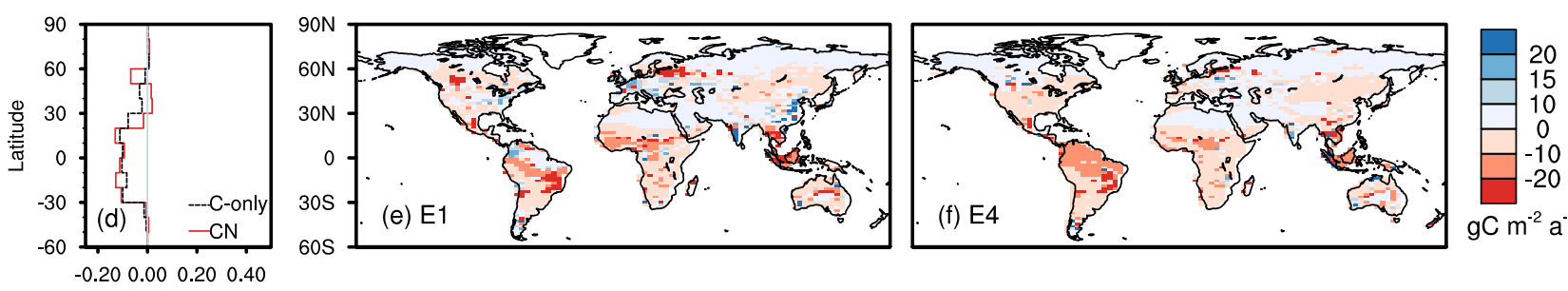

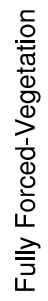
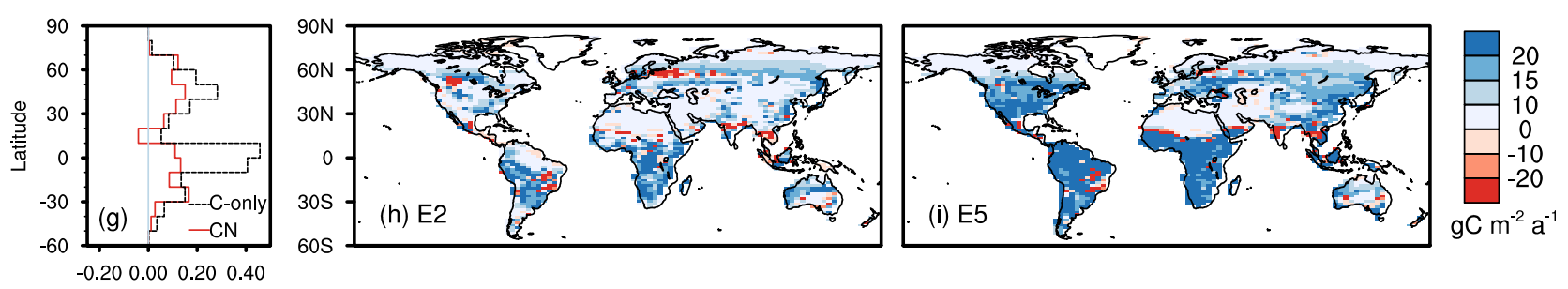

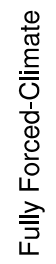
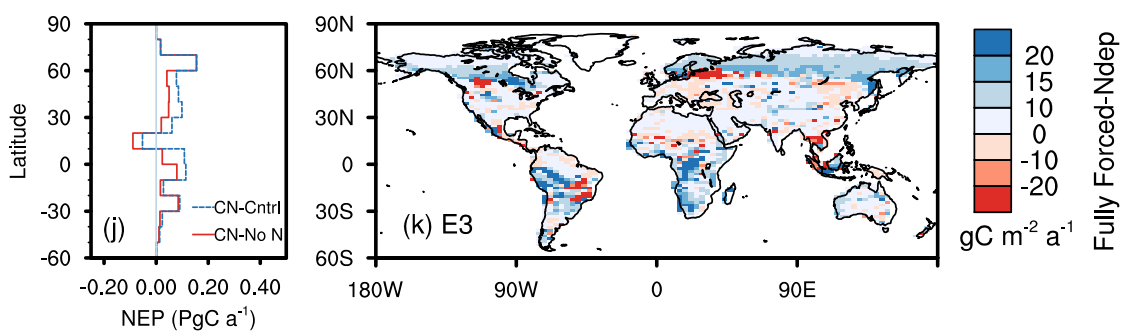

Fig. 9. Mean 1990-1999 Net Ecosystem Production (NEP); positive values indicate a C sink, negative values a C source. Zonal averages of NEP for UVic-CN (solid red) and UVic C-only (dashed black) in $10^{\circ}$ increments (a, d, g) and spatial distribution of NEP for UVic-CN (b, $\mathbf{e}, \mathbf{h}, \mathbf{k})$ and UVic C-only (c, f, i). In plot (j) the UVic-CN "Fully Forced-N dep" (solid red, "CN-No N") is compared to the UVic-CN "Fully Forced" (blue dashed, "CN cntrl"). Four sets of experiments are shown: "Fully Forced" (FF1 and FF2), "Fully Forced-Vegetation" (E1 for UVic-CN and E4 for UVic C-only), "Fully Forced-Climate" (E2 for UVic-CN and E5 for UVic C-only) and "Fully Forced-N dep" (E3). See Table 5 for the description of the experiments.

Both UVic model versions simulate a lower but broader peak around the tropics than the data of Beer et al. (2010) (Fig. 6a). The global simulated GPP of UVic-CN (129.6 $\left.\mathrm{Pg} \mathrm{C} \mathrm{yr}^{-1}\right)$ is in good agreement with the most recent, observation-based, estimate of $123 \pm 8 \mathrm{Pg} \mathrm{Cyr}^{-1}$ (Beer et al., 2010).

Vegetation $\mathrm{C}$ stocks are driven by wood density and are highest in tropical forests followed by temperate and boreal forests in UVic-CN (Fig. 7a). Simulated vegetation C stocks are $12-16 \mathrm{~kg} \mathrm{C} \mathrm{m}^{-2}$ for tropical forests and $4-12 \mathrm{~kg} \mathrm{C} \mathrm{m}^{-2}$ for temperate and boreal forests, which is close to observations that show mean values of $12.1 \mathrm{~kg} \mathrm{C} \mathrm{m}^{-2}$ for tropical and 5.7-6.4 for temperate and boreal forests (Malhi et al., 1999). Soil C stocks are highest in cold regions where decomposition rates are low (Fig. 7c). The differences between
UVic-CN and UVic C-only are shown on the right hand side of Fig. 7. The largest vegetation $\mathrm{C}$ gains in UVic-CN compared to UVic C-only are in the range of $3-5 \mathrm{~kg} \mathrm{C} \mathrm{m}^{-2}$ found in the circumpolar region, while tropical regions gain less C. The largest gains are found in the circumpolar regions because NPP is higher for UVic-CN than for UVic C-only. This seems counterintuitive as boreal ecosystems are thought of as being N-limited (Tamm, 1991) and we would expect a reduction of NPP when introducing $\mathrm{N}$ as a limiting factor. The fact that NPP of UVic-CN is higher in those regions (Fig. 6d) is due to the reduced autotrophic respiration in UVic-CN discussed above. However, when looking at GPP in Fig. 6a, we see that GPP values for both versions are very similar and very close to Beer et al. (2010)'s values. One reason for 
the similarity between UVic-CN and C-only is that the $\mathrm{N}$ input/output ratio in the boreal zone is greater than one, which means that there is no $\mathrm{N}$ limitation for boreal forests, suggesting that $\mathrm{N}$ input via BNF is too high. In fact, BNF in UVic-CN is $1-2 \mathrm{~g} \mathrm{~m}^{-2} \mathrm{yr}^{-1}$ in boreal forests, a factor of ten higher than estimates by Cleveland et al. (1999). Global BNF in the year 1999 for UVic-CN is $207 \mathrm{Tg} \mathrm{N} \mathrm{a}^{-1}$, derived as described in Sect. 2.2, and depends on estimates by Cleveland et al. (1999) whose best estimate is $195 \mathrm{~T} \mathrm{~N} \mathrm{a}^{-1}$ with a range of $100-290 \mathrm{~N} \mathrm{a}^{-1}$.

Soil $\mathrm{C}$ gains are highest in cold areas including the circumpolar region and the Tibetan plateau area, which decreases the discrepancy between modelled soil $\mathrm{C}$ stocks in the boreal region in UVic-CN and observations, e.g., Malhi et al. (1999) report an average of $34.3 \mathrm{~kg} \mathrm{C} \mathrm{m}^{-2}$ for boreal soils and the IGBP-DIS data shows high abundance of gridcells with a soil C content of $30 \mathrm{~kg} \mathrm{C}$ or more (Global Soil Data Task Group, 2000). Soil C in extra-boreal regions in UVic$\mathrm{CN}$ is generally higher than in UVic C-only, which brings the model results closer to observations, which are in the range of $9.6-12.3 \mathrm{~kg} \mathrm{C} \mathrm{m}^{-2}$ for the temperate and tropical regions, respectively (Fig. 7c, d). The differences in the $\mathrm{C}$ pools between UVic-CN and UVic C-only are almost the same for both steady state conditions, i.e., pre-industrial, and at the present day. The main reason for the increases in vegetation as well as soil $\mathrm{C}$ pools in UVic-CN especially in the boreal region is - as mentioned above - the enhanced NPP in UVic$\mathrm{CN}$, which leads to higher $\mathrm{C}$ accumulation rates.

Total global vegetation stocks are higher in UVic-CN than in UVic C-only due to higher NPP (Table 6), for which the reasons are discussed above. This is in contrast to Zaehle et al. (2010b) and Bonan and Levis (2010), who found a decrease in vegetation productivity when including $\mathrm{C} / \mathrm{N}$ interactions in their models and, therefore, lower vegetation $\mathrm{C}$ stocks. Soil C stocks are higher in UVic-CN than in UVic C-only - likely due to higher NPP values in UVic-CN - and are in agreement with Bonan and Levis (2010) but in disagreement with Zaehle et al. (2010b). In our case, soil C stocks increased when including $\mathrm{C} / \mathrm{N}$ interactions because the consideration of mineral $\mathrm{N}$ concentration in Eq. (5) leads to a faster humification process than when not including $\mathrm{C} / \mathrm{N}$ interactions, but it does not increase soil $\mathrm{C}$ turnover rates. Higher humification rates result in increased input into the slow overturning soil $\mathrm{C}$ pool at the expense of litter decomposition to $\mathrm{CO}_{2}$, thereby increasing the total $\mathrm{C}$ storage of the soil. The faster humification process and with it the faster litter decomposition (Eq. 7) lead to a smaller litter $\mathrm{C}$ pool in UVic-CN (Table 6).

\subsection{Historical changes of $\mathrm{C}$ fluxes and pools}

In Fig. 8 we compare how $\mathrm{C}$ fluxes and pools in UVic-CN and UVic C-only have evolved over the 19th and 20th century. GPP values of both versions increase over the last two centuries, remaining comparable up to the 1880 s, but diverg- ing from then on with UVic C-only increasing faster than UVic-CN (Fig. 8a). The point of divergence coincides with a change in radiative forcing caused by volcanic eruption of Krakatoa in 1883. Around 1883, both model versions show an increase in GPP followed by a decrease, though the decrease for UVic C-only is much smaller than that for UVic$\mathrm{CN}$. This difference in GPP fluctuations following volcanic eruptions can also be seen between 1800 and 1840. After each of the volcanic events, GPP first increases and then drops again. For UVic C-only, GPP rates drop back to the value observed before the volcanic event, but the GPP in UVic-CN shows a much stronger decrease after a preceding spike.

The reason why the UVic ESCM simulates an increase in GPP directly after volcanic eruptions is twofold. First, air temperature drops after volcanic eruptions due to an increase in aerosols (e.g., Harris and Highwood, 2011), which causes higher carbon assimilation rates in MOSES/TRIFFID (Cox et al., 1999, Eq. 15). Second, soil moisture increases due to a decrease in evaporation that exceeds the decrease in precipitation. Following (Cox et al., 1999, Eq. 18), an increase in soil moisture leads to higher $\mathrm{C}$ assimilation rates. The difference between UVic-CN and UVic C-only arises from the accumulation of $\mathrm{C}$ biomass through increased GPP; UVic-CN lags behind in acquiring enough $\mathrm{N}$ to maintain stable $\mathrm{C} / \mathrm{N}$ concentration ratios within the plant tissue and the increase in $\mathrm{C} / \mathrm{N}$ ratios negatively affects photosynthesis (Eq. 27). Global average $\mathrm{C} / \mathrm{N}$ ratios in leaves increase during each volcanic event and return to pre-event values afterwards. When comparing NPP (Fig. 8b) to heterotrophic respiration (HR) (Fig. 8c) we can see complementary patterns, i.e., when NPP shows a positive anomaly after a volcanic eruption, HR shows a negative one due to the opposite effect of temperature on those two variables. Lower temperature increases GPP and, hence, NPP in the UVic model, but it decreases soil and litter respiration rates. UVic-CN and UVic C-only show very similar trends up to 1960 , when they start diverging for both NPP and HR due to the higher GPP values.

The total land $\mathrm{C}$ pool shown in Fig. $8 \mathrm{f}$ is determined by the soil and litter $\mathrm{C}$ pools (Fig. 8e) which are much larger than the vegetation $\mathrm{C}$ pool (Fig. 8d). The vegetation $\mathrm{C}$ pools of UVic-CN and UVic C-only follow each other until 1960; the strong decrease between 1900 and 1960 is due to land use change. The difference between the two model versions is that the vegetation C pool in UVic C-only recovers from land use change at the beginning of the 1980s whereas UVicCN does not show a recovery at that point. By the year 1999, UVic-CN had lost 13.8 Pg C compared to the year 1800 , whereas UVic C-only had only lost $4.5 \mathrm{Pg}$ C. The main mechanism underlying the difference between the vegetation $\mathrm{C}$ pool in UVic C-only and UVic-CN after 1960 is that the growth rate of NPP in UVic C-only is greater than the growth rate of NPP in UVic-CN (Fig. 8b). The higher NPP growth rate permits recovery of the vegetation C after 1980 in UVic $\mathrm{C}$-only. The lower NPP growth rate in UVic-CN is caused 
Table 7. Climate sensitivities $\beta_{\mathrm{L}}$ in $\left(\mathrm{PgCppmv}^{-1}\right)$ and $\gamma_{\mathrm{L}}$ in $\left(\mathrm{Pg} \mathrm{C} \mathrm{K}{ }^{-1}\right.$ ) of the land $\mathrm{C}$ pool in UVic C-only and UVic-CN compared to other models.

\begin{tabular}{lcccl}
\hline Model & $\beta_{\mathrm{L}}$ & $\gamma_{\mathrm{L}}$ & Period & Reference \\
\hline UVic C-only & 1.2 & -103 & $1800-1999$ & this study \\
UVic-CN & 0.8 & -87 & $1800-1999$ & this study \\
O-C & 1.9 & -48 & $1860-2000$ & Zaehle et al. (2010a) \\
O-CN & 1.2 & -35 & $1860-2000$ & Zaehle et al. (2010a) \\
\hline
\end{tabular}

${ }^{1}$ : This is the value for the simulation labelled $\mathrm{CN}_{\text {ndep }}+\left(\Delta \Delta \mathrm{C}_{\mathrm{L}}^{\mathrm{NDEP}}\right)$ in Bonan and Levis (2010).

by the limiting effect of $\mathrm{N}$ availability which can be inferred from the increasing leaf $\mathrm{C} / \mathrm{N}$ ratios (data not shown).

The soil and litter $\mathrm{C}$ pool anomaly for UVic-CN is higher during the the first $150 \mathrm{yr}$ of the simulation, but even though it increases after 1960, it does not increase as fast as in UVic C-only, and the anomaly by the year 1999 is therefore higher for UVic C-only (72 Pg C) than for the UVic-CN (60.5 Pg C) (Fig. 8e). This pattern also dominates the total $\mathrm{C}$ shown in Fig. 8f, which shows that between 1800 and 1960, the terrestrial biosphere gained up to $20 \mathrm{PgC}$ and between 1960 and 1999 it gained another $26-47 \mathrm{Pg} \mathrm{C}$ depending on the model version. A difference of $21 \mathrm{Pg} \mathrm{C}$ in total $\mathrm{C}$ accumulation by the year 1999 compares well to the O-CN model, in which the $\mathrm{O}-\mathrm{C}$ version gained $25 \mathrm{Pg} \mathrm{C}$ more than the $\mathrm{O}-\mathrm{CN}$ version in the period 1860-2000 (Zaehle et al., 2010a, Table S1).

\subsection{Sensitivity of land C uptake}

The climate sensitivities, $\beta_{\mathrm{L}}$ and $\gamma_{\mathrm{L}}$, for the period 18001999 are listed in Table 7. The current version of the UVic model simulates a $\beta_{\mathrm{L}}$ value of 1.2 for UVic C-only and $0.8 \mathrm{Pg} \mathrm{Cppmv}^{-1}$ for UVic-CN. A similar magnitude of reduction of the $\beta_{\mathrm{L}}$ sensitivity when including $\mathrm{C} / \mathrm{N}$ interactions is also found in the O-CN model (Table 7). The $\beta_{\mathrm{L}}$ for UVic$\mathrm{CN}$ is $0.4 \mathrm{Pg} \mathrm{C}_{\mathrm{ppmv}^{-1}}(-33 \%)$ lower than for UVic C-only, whereas for $\mathrm{O}-\mathrm{CN}$ the respective change is $0.6 \mathrm{Pg} \mathrm{C}_{\mathrm{ppmv}}{ }^{-1}$ $(-32 \%)$. This means that introducing $\mathrm{C} / \mathrm{N}$ feedbacks into those two models had a similarly strong effect on the $\mathrm{C}$ sensitivity to $\mathrm{CO}_{2}$ fertilisation.

The $\mathrm{C}$ sensitivity to temperature, $\gamma_{\mathrm{L}}$, is $-103 \mathrm{Pg} \mathrm{C} \mathrm{K}^{-1}$ for UVic C-only and $-87 \mathrm{Pg} \mathrm{C} \mathrm{K}^{-1}$ for UVic-CN, which makes it more sensitive to temperature than the $\mathrm{O}-\mathrm{CN}$ model, whose $\mathrm{C}$ sensitivity to temperature is only $-48 \mathrm{PgC} \mathrm{K}^{-1}$ for the C-only version and $-35 \mathrm{Pg} \mathrm{C} \mathrm{K}^{-1}$ for the $\mathrm{CN}$ version (Table 7). The greater sensitivity of the UVic model is not surprising, as in a multi-model comparison of climate sensitivities, $\gamma_{\mathrm{L}}$ of the UVic ESCM was $-98 \mathrm{Pg} \mathrm{C} \mathrm{K}^{-1}$ for the period 1850-2100, which was greater than the multi-model average of $-79 \mathrm{PgC} \mathrm{K}^{-1}$ (Friedlingstein et al., 2006). The relative change of $\gamma_{\mathrm{L}}$ when switching from the C-only to the $\mathrm{CN}$ version in the UVic ESCM $(-25 \%)$ is comparable to the one in O-CN $(-27 \%)$, whereas, the absolute change of the UVic
ESCM is twice as high as the change of the O-CN model ( 26 vs. $13 \mathrm{Pg} \mathrm{C} \mathrm{K}^{-1}$ ), which can be explained by the higher sensitivity of the UVic C-only.

In order to evaluate the sensitivity of the land $\mathrm{C}$ uptake to the introduction of $\mathrm{N}$ into the UVic model, we compare the spatial distribution and the zonal averages of Net Ecosystem Production (NEP), i.e., the $\mathrm{CO}_{2}$ flux from the atmosphere to the land, of UVic-CN to UVic C-only under different forcing regimes for the 1990s (Fig. 9). UVic C-only simulates a strong $\mathrm{C}$ sink in tropical regions and a less strong $\mathrm{C}$ sink for the extra-tropical regions for the 1990s under the "Fully Forced" experiment (Fig. 9c). Almost all of the Amazon, tropical Africa and parts of Southeast Asia take up $\mathrm{C}$ at a rate of over $20 \mathrm{~g} \mathrm{C} \mathrm{m}^{-2} \mathrm{a}^{-1}$. A large proportion of these tropical C sinks disappears in UVic-CN (Fig. 9b), whereas the boreal C sinks remain. The disappearance of the tropical $\mathrm{C}$ sinks is not caused by $\mathrm{N}$ limitation in the model, given that zonally averaged GPP values of UVic-CN and UVic C-only do not differ much (Fig. 6a) and NPP values in the tropics are actually higher in UVic-CN than in UVic C-only (Fig. 6d). The neutral NEP in the tropics is due to an increase in heterotrophic respiration in the tropics in UVic-CN. This increase is caused by a faster rate of litter decomposition due to the inclusion of the effect of $\mathrm{N}$ on humification discussed above, but also by the increase of the soil C pool in UVic-CN (Fig. 7).

Expressed as zonal averages, NEP around the equator shows a reduction from about $0.35 \mathrm{Pg} \mathrm{Ca}^{-1}$ per $10^{\circ}$ latitude in UVic C-only to $0.1 \mathrm{PgCa}^{-1}$ in UVic-CN (Fig. 9a). Another reduction in the $\mathrm{C}$ sink strength is seen in the midlatitudes, between $40^{\circ} \mathrm{N}$ and $60^{\circ} \mathrm{N}$; here, a drop from about $0.2 \mathrm{Pg} \mathrm{Ca}^{-1}$ in UVic C-only to $<0.1 \mathrm{Pg} \mathrm{Ca}^{-1}$ in UVic-CN is observed. A reduction in NEP in the tropics and the midnorthern latitudes is also observed in the MIT CN-TEM model when compared to the MIT C-TEM model (Sokolov et al., 2008). When comparing our results to those of the O$\mathrm{CN}$ model, we find two main differences: first, zonally averaged NEP in both, the O-C and O-CN versions, for the 1990 s is larger in mid-latitudes $\left(>0.4 \mathrm{Pg} \mathrm{Ca}^{-1}\right)$ than in low latitudes $\left(<0.4 \mathrm{Pg} \mathrm{Ca}^{-1}\right)$, and second, the zonally averaged NEP south of $50^{\circ} \mathrm{N}$ in $\mathrm{O}-\mathrm{CN}$ is higher than in O-C (Zaehle et al., 2010b), which contrasts with the results of the UVic $\mathrm{C}$-only and $\mathrm{CN}$-coupled versions. The effect that $\mathrm{N}$ has on the NEP in Fig. 9a is caused by an increase in heterotrophic respiration due to mineral $\mathrm{N}$ availability. This increase leads to lower NEP despite equal or higher NPP in the tropics as shown in Fig. 6 d.

In the "Fully Forced minus Vegetation" experiment, where the vegetation experiences constant atmospheric $\mathrm{CO}_{2}$ concentrations at 1800 levels, whereas climate and $\mathrm{N}$ deposition are transient, almost all of the land area turns into a $\mathrm{C}$ source (Fig. 9d-f). In UVic C-only the Amazon is a stronger $\mathrm{C}$ source than in UVic-CN, but the opposite is true for Southeast Asia. When comparing the "Fully Forced" to the "Fully Forced minus Vegetation" experiments a larger decrease of tropical NEP is observed in UVic C-only than in UVic-CN, 
Table 8. Global NEP $\left(\mathrm{Pg} \mathrm{Ca}^{-1}\right)$ values for the 1990s.

\begin{tabular}{lcccc}
\hline Forcing & Experiment & CN-coupled & Experiment & C-only \\
\hline Fully Forced & FF1 & 0.83 & FF2 & 1.57 \\
Fully Force minus Vegetation & E1 & -0.60 & E4 & -0.63 \\
Fully Force minus Climate & E2 & 1.05 & E5 & 2.17 \\
Fully Force minus N deposition & E3 & 0.48 & & \\
\hline
\end{tabular}

bringing the NEP values of UVic C-only and UVic-CN closer to each other between $50^{\circ} \mathrm{S}$ and $20^{\circ} \mathrm{N}$ (Fig. 9d). Tropical NEP in UVic C-only decreases by $0.39-0.43 \mathrm{Pg} \mathrm{Ca}^{-1}$ per $10^{\circ}$-latitude band, whereas in UVic-CN, it decreases by only $0.20-0.23 \mathrm{Pg} \mathrm{Ca}^{-1}$. The stronger reduction in NEP in UVic C-only compared to UVic-CN has also been found in O-CN (Zaehle et al., 2010b). In our model, this difference is due to a reduction in NPP that averages $16.4 \%$ between $30^{\circ} \mathrm{S}$ and $30^{\circ} \mathrm{N}$ in UVic C-only but only $12.9 \%$ in UVic-CN.

The "Fully Forced minus Climate" experiment, basically a $\mathrm{CO}_{2}$ fertilisation experiment, results in an increase of NEP compared to the "Fully Forced" experiment in UVic C-only between $30^{\circ} \mathrm{S}$ and $60^{\circ} \mathrm{N}$, with the strongest increase around the equator of $0.12 \mathrm{Pg} \mathrm{Ca}^{-1}$ per $10^{\circ}$-latitude band (Fig. $9 \mathrm{~g}-$ i). In contrast, UVic-CN does not show increases of NEP around the equator, but rather in mid-latitudes, i.e., $10^{\circ} \mathrm{S}-$ $30^{\circ} \mathrm{S}$ and $40^{\circ} \mathrm{N}-50^{\circ} \mathrm{N}$.

The last experiment, "Fully Forced minus N deposition" is similar to the Fully Forced experiment, except that $\mathrm{N}$ deposition is excluded from the model. As the zonal average shows, the simulation without $\mathrm{N}$ deposition has a reduced $\mathrm{C}$ sink strength between $10^{\circ} \mathrm{S}$ and $60^{\circ} \mathrm{N}$, in the areas where $\mathrm{N}$ deposition occurs (Dentener, 2006). Zaehle et al. (2010b) found that the latitudes between $35^{\circ} \mathrm{N}$ and $65^{\circ} \mathrm{N}$ are most affected by $\mathrm{N}$ deposition in the O-CN model. The sensitivity of the UVic model to $\mathrm{N}$ deposition in the tropics together with the lack of increase in NEP in the "Fully Forced minus Climate" experiment is likely to be related to changes in the Amazon basin.

Throughout the figures, the Amazon basin differs from other tropical regions, showing lower ammonium and nitrate concentration (Fig. 4), lower plant uptake (Fig. 5a), partially in GPP and NPP (Fig. 6). One difference between the Amazon and the rest of the tropics that we have found is a much higher simulated soil moisture. Higher soil moisture leads to higher runoff and despite lower ammonium and nitrate concentrations, leaching rates of mineral $\mathrm{N}$ are about the same in the Amazon as in other tropical regions (Fig. 5b), which means that in our model relatively more mineral $\mathrm{N}$ is lost via leaching in the Amazon than in other regions. Lower soil ammonium and nitrate concentrations cause lower plant uptake rates, leading to higher leaf $\mathrm{C} / \mathrm{N}$ ratios in the northern part of the Amazon (compare Figs. 3b, 4a and 5a), which limits photosynthesis.
Global numbers for NEP shown in Fig. 9 are given in Table 8. The difference in NEP between UVic C-only (FF2) and UVic-CN (FF2) is $0.74 \mathrm{Pg} \mathrm{Ca}^{-1}$ in the "Fully Forced" simulations. This drop in NEP is simulated despite the increase in NPP in UVic-CN discussed above; the lower NEP is caused by higher soil and litter respiration rates reducing the $\mathrm{C}$ sink strength in UVic-CN. A drop of $0.7 \mathrm{Pg} \mathrm{Ca}^{-1}$ from the Conly to the CN-coupled version is also found in the CLM4 model (Bonan and Levis, 2010). The model experiments "Fully Forced minus Vegetation" result in the land becoming a strong $\mathrm{C}$ source in both model versions. Land in UVic Conly represents a slightly stronger $\mathrm{C}$ source $\left(-0.63 \mathrm{Pg} \mathrm{Ca}^{-1}\right)$ than in UVic-CN $\left(-0.60 \mathrm{Pg} \mathrm{Ca}^{-1}\right)$. The difference between the $\mathrm{CN}$-coupled version and the C-only version in the UVic model is smaller than that found by Zaehle et al. (2010b, approximately $-0.7 \mathrm{Pg} \mathrm{Ca}^{-1}$ for the O-C and -0.3 for O$\mathrm{CN})$. The smaller difference between the two UVic versions may be the result of the absence of $\mathrm{N}$ limitation in the boreal zone (Fig. 9a) due to high rates of BNF in the UVic-CN as discussed above. The lack of boreal $\mathrm{N}$ limitation will cause global C storage to appear higher than they may be in reality and a reduction of NEP as seen in the O-C/O-CN versions is more likely.

When the model is integrated in the "Fully Forced minus Climate" mode, we observe a larger increase in global NEP in UVic C-only (from 1.57 to $2.17 \mathrm{PgC} \mathrm{a}^{-1}$ ) than in UVic$\mathrm{CN}$ (from 0.83 to $1.05 \mathrm{PgC} \mathrm{a}^{-1}$ ) compared to the "Fully Forced" simulations (Table 8). The global effect of excluding $\mathrm{N}$ deposition is a reduction of the annual NEP from $0.83 \mathrm{Pg} \mathrm{Ca}^{-1}$ to $0.48 \mathrm{Pg} \mathrm{Ca}^{-1}$ or, expressed as the positive effect of anthropogenic $\mathrm{N}$ deposition, we find an enhancement of NEP of $0.35 \mathrm{Pg} \mathrm{Ca}^{-1}$, which falls in the range of the estimates by Zaehle et al. (2010b) of $0.2-0.5 \mathrm{Pg} \mathrm{Ca}^{-1}$.

Comparing the additive effect of the climate experiments $(\mathrm{E} 1+\mathrm{E} 2$ and $\mathrm{E} 4+\mathrm{E} 5)$ with the fully forced simulations (FF1 and FF2), we find a strong nonlinearity in UVic-CN $\left(\mathrm{FF} 1 \neq \mathrm{E} 1+\mathrm{E} 2\right.$, i.e., $\left.0.83 \neq 0.45 \mathrm{Pg} \mathrm{Ca}^{-1}\right)$, but only a weak nonlinearity in UVic C-only (FF2 $\approx \mathrm{E} 4+\mathrm{E} 5$, i.e., $1.57 \approx$ $1.54 \mathrm{Pg} \mathrm{Ca}^{-1}$ ) (Table 8). A similar nonlinearity has been found in O-CN by Zaehle et al. (2010b), who compared their "Fully Forced" version to the "Fully Forced minus Vegetation" + "Fully Forced minus Climate" (all three versions are without $\mathrm{N}$ deposition) and found a difference of $0.4 \mathrm{Pg} \mathrm{Ca}^{-1}$, i.e., the NEP of the "Fully Forced" is $0.4 \mathrm{Pg} \mathrm{Ca}^{-1}$ higher than 
the arithmetic sum of the other two simulations. In our case, that difference is $0.38 \mathrm{Pg} \mathrm{Ca}^{-1}$.

\section{Conclusions}

The UVic ESCM joins a suite of other Earth System Models that have included terrestrial $\mathrm{C} / \mathrm{N}$ feedbacks. There is large uncertainty around some of the relevant pool sizes (e.g., $\mathrm{N}$ pool in vegetation, $\mathrm{NO}_{3}^{-}$pool in soils) and flux strengths (e.g., $\mathrm{N}$ uptake or leaching), which cannot be eliminated until we have gathered better data. The UVic ESCM agrees with some models and disagrees with others, but shows, in general, similar behaviour to other $\mathrm{CN}$-coupled models; where disagreement occurs, there exists a reasonable explanation for differences between our model and others. One of the main attributes of the UVic CN-coupled ESCM is that the inclusion of $\mathrm{N}$ leads to an increase in the NPP:GPP ratio which is caused by a reduction in autotrophic respiration due to its relationship with plant $\mathrm{N}$ content. Even though the current formulation of the autotrophic respiration served the C-only version of the model well, the shift in NPP:GPP ratio from UVic C-only to UVic-CN suggests that it may be unrealistic for a $\mathrm{CN}$-coupled version and should be reconsidered in a future version.

The high soil moisture content in the Amazonian basin are the reason why this region stands out compared to other tropical areas. Higher soil moisture content leads to faster microbial processes, causing low mineral $\mathrm{N}$ concentrations. The Amazonian basin shows lower productivity values and a nearly neutral NEP and only minor changes in our forcing experiments. The overall cause for the high soil moisture values in the Amazon is a bias towards high precipitation in that region in the UVic ESCM. The absence of $\mathrm{N}$ limitation in the boreal forest appears to be due to too much $\mathrm{N}$ input via $\mathrm{BNF}$ in those regions.

Despite these limitations, the changes of climate sensitivity to $\mathrm{CO}_{2}$ and temperature when introducing $\mathrm{C} / \mathrm{N}$ feedbacks to the UVic model compares well to the more sophisticated O-CN model. Similar to other models, we find that the coupling of the $\mathrm{C}$ and $\mathrm{N}$ cycle leads to reductions in NEP under fully forced conditions and introduces a strong nonlinear behaviour in NEP. This nonlinearity arises either from a mitigated negative effect of temperature on NEP or a suppressed positive effect of $\mathrm{CO}_{2}$ on NEP.

Acknowledgements. We would like to thank Stefan Gerber and Barbara Hawkins for scientific advice and discussion, Chris Avis for help with parameters and Edward Wiebe for technical support. We would also like to thank Sönke Zaehle and one anonymous reviewer for their constructive comments. We are grateful for support from NSERC accelerator, NSERC CREATE and ARC Future Fellow schemes.

Edited by: D. Lawrence

\section{References}

Archer, D.: A data-driven model of the global calcite lysocline, Global Biogeochem. Cy., 10, 511-526, 1996.

Arora, V. K. and Matthews, H. D.: Characterizing uncertainty in modeling primary terrestrial ecosystem processes, Global Biogeochem. Cy., 23, GB2016, doi:10.1029/2008GB003398, 2009.

Bai, E., Houlton, B. Z., and Wang, Y. P.: Isotopic identification of nitrogen hotspots across natural terrestrial ecosystems, Biogeosciences, 9, 3287-3304, doi:10.5194/bg-9-3287-2012, 2012.

Batjes, N. H.: Total carbon and nitrogen in the soils of the world, Europ. J. Soil Sci., 47, 151-163, 1996.

Beer, C., Reichstein, M., Tomelleri, E., Ciais, P., Jung, M., Carvalhais, N., Rodenbeck, C., Arain, M. A., Baldocchi, D., Bonan, G. B., Bondeau, A., Cescatti, A., Lasslop, G., Lindroth, A., Lomas, M., Luyssaert, S., Margolis, H., Oleson, K. W., Roupsard, O., Veenendaal, E., Viovy, N., Williams, C., Woodward, F. I., and Papale, D.: Terrestrial gross carbon dioxide uptake: Global distribution and covariation with climate, Science, 329, 834-838, 2010.

Bengtsson, G., Bengtson, P., and Møansson, K. F.: Gross nitrogen mineralization-, immobilization-, and nitrification rates as a function of soil $\mathrm{C} / \mathrm{N}$ ratio and microbiabl activity, Soil Biol. Biochem., 35, 143-154, 2003.

Bonan, G. B. and Levis, S.: Quantifying carbon-nitrogen feedbacks in the Community Land Model (CLM4), Geophys. Res. Lett., 37, 2261-2282, 2010.

Cleveland, C. C., Townsend, A. R., Schimel, D. S., Fisher, H., Howarth, R. W., Hedin, L. O., Perakis, S. S., Latty, E. F., Fischer, J. C. V., Elseroad, A., and Wasson, M. F.: Global patterns of terrestrial biological nitrogen $\left(\mathrm{N}_{2}\right)$ fixation in natural ecosystems, Global Biogeochem. Cy., 13, 623-645, 1999.

Cox, P. M.: Description of the TRIFFID dynamic global vegetation model, Tech. Rep. 24, Hadley Centre, Met office, London Road, Bracknell, Berks, RG122SY, UK, 2001.

Cox, P. M., Betts, R. A., Bunton, C. B., Essery, R. L. H., Rowntree, P. R., and Smith, J.: The impact of new land surface physics on the GCM simulation of climate and climate sensitivity, Clim. Dynam., 15, 183-203, 1999.

Denman, K. L., Brasseur, G., Chidthaisong, A., Ciais, P., Cox, P. M., Dickinson, R. E., Hauglustaine, D., Heinze, C., Holland, E., Jacob, D., Lohmann, U., Rmachandran, S., da Silva Dias, P. L., Wofsy, S. C., and Zhang, X.: Couplings between changes in the climate system and biogeochemistry, in: Solomon et al. (2007), chap. 7, 499-588, 2007.

Dentener, F. J.: Global maps of atmospheric nitrogen deposition, 1860, 1993, 2050., Data set., Oak Ridge National Laboratory Distributed Active Archive Center, Oak Ridge, Tennessee, U.S.A., http://daac.ornl.gov/, 2006.

Eby, M., Zickfeld, K., Montenegro, A., Archer, D., Meissner, K. J., and Weaver, A. J.: Lifetime of anthropogenic climate change: Millennial time scales of potential $\mathrm{CO}_{2}$ and surface temperature perturbations, J. Climate, 22, 2501-2511, 2009.

Esser, G., Kattge, J., and Sakalli, A.: Feedback of carbon and nitrogen cycles enhances carbon sequestration in the terrestrial biosphere, Glob. Change Biol., 17, 819-842, 2011.

Evans, J. R.: Nitrogen and photosynthesis in the flag leaf of wheat (Triticum aestivum L.), Plant Physiol., 72, 297-302, 1983.

Friedlingstein, P. and Prentice, I. C.: Carbon-climate feedbacks: a review of model and observation based estimates, Curr. Opin. 
Environ. Sustain., 2, 1-7, 2010.

Friedlingstein, P., Cox, P., Betts, R., Bopp, L., Bloh, W. V., Brovkin, V., Cadule, P., Doney, S., Eby, M., Fung, I., Bala, G., John, J., Jones, C., Joos, F., Kato, T., Kawamiya, M., Knorr, W., Lindsay, K., Matthews, H. D., Raddatz, T., Rayner, P., Reick, C., Roeckner, E., Schnitzler, K. G., Schnur, R., Strassmann, K., Weaver, A. J., Yoshikawa, C., and Zeng, N.: Climate-carbon cycle feedback analysis: Results from the $\mathrm{C}^{4} \mathrm{MIP}$ model intercomparison, J. Climate, 19, 3337-3353, 2006.

Gai-ping, C., Lei, C., Jian-guo, Z., Jing, P., Zu-bin, X., and Qing, Z.: Effects of Free-air $\mathrm{CO}_{2}$ Enrichment on root characteristics and C:N ratio of rice at the heading stage, Rice Science, 13, 120 $124,2006$.

Galloway, J. N., Dentener, F. J., Capone, D. G., Boyer, E. W., Howarth, R. W., Seitzinger, S. P., Asner, G. P., Cleveland, C. C., Green, P. A., Holland, E. A., Karl, D. M., Michaels, A. F., Porter, J. H., Townsend, A. R., and Vorosmarty, C. J.: Nitrogen cycles: past, present, and future, Biogeochemistry, 70, 153-226, 2004.

Garten Jr., C. T., Iversen, C. M., and Norby, R. J.: Litterfall ${ }^{15} \mathrm{~N}$ abundance indicates declining soil nitrogen availability in a freeair $\mathrm{CO}_{2}$ experiment, Ecology, 92, 133-139, 2011.

Gerber, S., Hedin, L. O., Oppenheimer, M., Pacala, S. W., and Shevliakova, E.: Nitrogen cycling and feedbacks in a global dynamic land model, Global Biogeochem. Cy., 24, 121-149, 2010.

Global Soil Data Task Group: Global gridded surfaces of selected soil characteristics (IGBP-DIS), Oak Ridge National Laboratory Distributed Active Archive Center, Oak Ridge, Tennessee, U.S.A., http://www.daac.ornl.gov, 2000.

Goll, D. S., Brovkin, V., Parida, B. R., Reick, C. H., Kattge, J., Reich, P. B., van Bodegom, P. M., and Niinemets, Ü.: Nutrient limitation reduces land carbon uptake in simulations with a model of combined carbon, nitrogen and phosphorus cycling, Biogeosciences Discuss., 9, 3173-3232, doi:10.5194/bgd-9-3173-2012, 2012.

Gregory, J. M., Dixon, K. W., Stouffer, R. J., Weaver, A. J., Driesschaert, E., Eby, M., Fichefet, T., Hasumi, H., Hu, A., Jungclaus, J. H., Kamenkovich, I. V., Levermann, A., Montoya, M., Murakami, S., Nawrath, S., Oka, A., Sokolov, A. P., and Thorpe, R. B.: A model intercomparison of changes in the Atlantic thermohaline circulation in response to increasing atmospheric $\mathrm{CO}_{2}$ concentration, Geophys. Res. Lett., 32, 1365-1387, 2005.

Gruber, N. and Galloway, J. N.: An Earth-system perspective of the global nitrogen cycle, Nature, 451, 293-296, 2008.

Harris, B. M. and Highwood, E. J.: A simple relationship between volcanic sulfate aerosol optical depth and surface temperature change simulated in an atmosphere-ocean general circulation model, J. Geophys. Res.-Atmos., 116, 2258-2270, 2011.

Hickler, T., Smith, B., Prentice, I. C., Mjöfors, K., Miller, P., Arneth, A., and Sykes, M. T.: $\mathrm{CO}_{2}$ fertilization in temperate FACE experiments not representative of boreal and tropical forests, Glob. Change Biol., 14, 1531-1542, doi:10.1111/j.13652486.2008.01598.x, 2008.

Hollinger, D. Y.: Optimality and nitrogen allocation in a tree canopy, Tree Physiol., 16, 627-634, 1996.

Jain, A., Yang, X. J., Kheshgi, H., McGuire, A. D., Post, W., and Kicklighter, D.: Nitrogen attenuation of terrestrial carbon cycle response to global environmental factors, Global Biogeochem. Cy., 23, 121-149, 2009.
Lambers, H., Chapin III, F. S., and Pons, T. L.: Plant Physiological Ecology, Springer-Verlag New York, LLC, 2nd edn., 2008.

Lin, B. L., Sakoda, A., Shibasaki, R., Goto, N., and Suzuki, M.: Modelling a global biogeochemical nitrogen cycle in terrestrial ecosystems, Ecol. Model., 135, 89-110, 2000.

Liu, L., King, J. S., and Giardina, C. P.: Effects of elevated concentrations of atmospheric $\mathrm{CO}_{2}$ and tropospheric $\mathrm{O}_{3}$ on leaf litter production and chemistry in trembling aspen and paper birch communities, Tree Physiol., 25, 1511-1522, 2005.

Luyssaert, S., Inglima, I., Jung, M., Richardson, A. D., Reichsteins, M., Papale, D., Piao, S. L., Schulzes, E. D., Wingate, L., Matteucci, G., Aragao, L., Aubinet, M., Beers, C., Bernhoffer, C., Black, K. G., Bonal, D., Bonnefond, J. M., Chambers, J., Ciais, P., Cook, B., Davis, K. J., Dolman, A. J., Gielen, B., Goulden, M., Grace, J., Granier, A., Grelle, A., Griffis, T., Grunwald, T., Guidolotti, G., Hanson, P. J., Harding, R., Hollinger, D. Y., Hutyra, L. R., Kolar, P., Kruijt, B., Kutsch, W., Lagergren, F., Laurila, T., Law, B. E., Maire, G. L., Lindroth, A., Loustau, D., Malhi, Y., Mateus, J., Migliavacca, M., Misson, L., Montagnani, L., Moncrieff, J., Moors, E., Munger, J. W., Nikinmaa, E., Ollinger, S. V., Pita, G., Rebmann, C., Roupsard, O., Saigusa, N., Sanz, M. J., Seufert, G., Sierra, C., Smith, M. L., Tang, J., Valentini, R., Vesala, T., and Janssens, I. A.: $\mathrm{CO}_{2}$ balance of boreal, temperate, and tropical forests derived from a global database, Glob. Change Biol., 13, 2509-2537, 2007.

Malhi, Y., Baldocchi, D. D., and Jarvis, P. G.: The carbon balance of tropical, temperate and boreal forests, Plant Cell Environ., 22, 715-740, 1999.

Martius, C.: Density, humidity, and nitrogen content of dominant wood species of floodplain forests (várzea) in Amazonia, Holz Roh Werkst., 50, 300-303, 1992.

Matthews, H. D., Weaver, A. J., Meissner, K. J., Gillett, N. P., and Eby, M.: Natural and anthropogenic climate change: incorporating historical land cover change, vegetation dynamics and the global carbon cycle, Clim. Dynam., 22, 461-479, 2004.

McCarthy, H. R., Oren, R., Johnsen, K. H., Gallet-Budynek, A., Pritchard, S. G., Cook, C. W., LaDeau, S. L., Jackson, R. B., and Finzi, A. C.: Re-assessment of plant carbon dynamics at the Duke free-air $\mathrm{CO}_{2}$ enrichment site: interactions of atmospheric $\left[\mathrm{CO}_{2}\right]$ with nitrogen and water availability over stand development, New Phytol., 185, 514-528, 2010.

Meehl, G. A., Stocker, T. F., Collins, W. D., Friedlingstein, P., Gaye, A. T., Gregory, J. M., Kitoh, A., Knutti, R., Murphy, J. M., Noda, A., Raper, S. C. B., Watterson, I. G., Weaver, A. J., and Zhao, Z.-C.: Global climate projections, in: Solomon et al. (2007), chap. 10, 747-846, 2007.

Meissner, K. J., Weaver, A. J., Matthews, H. D., and Cox, P. M.: The role of land surface dynamics in glacial inception: a study with the UVic Earth System Model, Clim. Dynam., 21, 515-537, 2003.

Norby, R. J., DeLucia, E. H., Gielen, B., Calfapietra, C., Giardina, C. P., King, J. S., Ledford, J., McCarthy, H. R., Moore, D. J. P., Ceulemans, R., Angelis, P. D., Finzi, A. C., Karnosky, D. F., Kubiske, M. E., Lukac, M., Pregitzer, K. S., Scarascia-Mugnozza, G. E., Schlesinger, W. H., and Oren, R.: Forest response to elevated $\mathrm{CO}_{2}$ is conserved across a broad range of productivity, Proc. Natl. Acad. Sci. USA, 102, 18052-18056, 2005.

Norby, R. J., Warren, J. M., Iversen, C. M., Medlyn, B. E., and McMurtrie, R. E.: $\mathrm{CO}_{2}$ enhancement of forest productivity 
constrained by limited nitrogen availability, P. Natl. Acad Sci. USA, 107, 19368-19373, 2010.

Pendall, E., Mosier, A. R., and Morgan, J. A.: Rhizodeposition stimulated by elevated $\mathrm{CO}_{2}$ in a semiarid grassland, New Phytol., 162, 447-458, 2004.

Plattner, G.-K., Knutti, R., Joos, F., Stocker, T. F., von Bloh, W., Brovkin, V., Cameron, D., Driesschaert, E., Dutkiewicz, S., Eby, M., Edwards, N. R., Fichefet, T., Hargreaves, J. C., Jones, C. D., Loutre, M. F., Matthews, H. D., Mouchet, A., Müller, S. A., Nawrath, S., Price, A., Sokolov, A., Strassmann, K. M., and Weaver, A. J.: Long-term climate commitments projected with climate-carbon cycle models, J. Climate, 21, 2721-2751, 2008.

Post, W. M., Pastor, J., Zinke, P. J., and Stangenberger, A. G.: Global patterns of soil-nitrogen storage, Nature, 317, 613-616, 1985.

Ramankutty, N. and Foley, J. A.: Estimating historical changes in global land cover: Croplands from 1700 to 1992, Global Biogeochem. Cy., 13, 997-1027, doi:10.1029/1999GB900046, 1999.

Saugier, B. and Roy, J.: Estimations of global terrestrial productivity: Converging towards a single number?, in: Global terrestrial productivity: Past, present and future, edited by Mooney, H., Roy, J., and Saugier, B., Academic, San Diego, California, 2001.

Schmittner, A.: Decline of the marine ecosystem caused by a reduction in the Atlantic overturning circulation, Nature, 434, 628633, 2005.

Schmittner, A., Oschlies, A., Matthews, H. D., and Galbraith, E. D.: Future changes in climate, ocean circulation, ecosystems, and biogeochemical cycling simulated for a business-as-usual $\mathrm{CO}_{2}$ emission scenario until year 4000 AD, Global Biogeochem. Cy., 22, 2501-2511, 2008.

Sitch, S., Smith, B., Prentice, I. C., Arneth, A., Bondeau, A., Cramer, W., Kaplan, J. O., Levis, S., Lucht, W., Sykes, M. T., Thonicke, K., and Venevsky, S.: Evaluation of ecosystem dynamics, plant geography and terrestrial carbon cycling in the LPJ dynamic global vegetation model, Glob. Change Biol., 9, 161-185, 2003.

Sokolov, A. P., Kicklighter, D. W., Melillo, J. M., Felzer, B. S., Schlosser, C. A., and Cronin, T. W.: Consequences of considering carbon-nitrogen interactions on the feedbacks between climate and the terrestrial carbon cycle, J. Climate, 21, 3776-3796, 2008.

Solomon, S., Qin, D., Manning, M., Chen, Z., Marquis, M., Averyt, K. B., Tignor, M., and Miller, H. L., eds.: Cambridge University Press, Cambridge, United Kingdom and New York, NY, USA, 2007.

Stouffer, R. J., Yin, J., Gregory, J. M., Dixon, K. W., Spelman, M. J., Hurlin, W., Weaver, A. J., Eby, M., Flato, G. M., Hasumi, H., Hu, A., Jungclaus, J. H., Kamenkovich, I. V., Levermann, A., Montoya, M., Murakami, S., Nawrath, S., Oka, A., Peltier, W. R., Robitaille, D. Y., Sokolov, A., Vettoretti, G., and Weber, S. L.: Investigating the causes of the response of the thermohaline circulation to past and future climate changes, J. Climate, 19, 13651387, 2006.

Tamm, C. O.: Nitrogen in terrestrial ecosystems: Questions of productivity, vegetational changes, and ecosystem stability, vol. 81 of Ecological Studies, Springer, 115 pp., 1991.

Thornton, P. E. and Zimmermann, N. E.: An improved canopy integration scheme for a land surface model with prognostic canopy structure, J. Climate, 20, 3902-3923, 2007.
Thornton, P. E., Lamarque, J. F., Rosenbloom, N. A., and Mahowald, N. M.: Influence of carbon-nitrogen cycle coupling on land model response to $\mathrm{CO}_{2}$ fertilization and climate variability, Global Biogeochem. Cy., 21, GB4018, doi:10.1029/2006GB002868, 2007.

Thornton, P. E., Doney, S. C., Lindsay, K., Moore, J. K., Mahowald, N., Randerson, J. T., Fung, I., Lamarque, J.-F., Feddema, J. J., and Lee, Y.-H.: Carbon-nitrogen interactions regulate climate-carbon cycle feedbacks: results from an atmosphereocean general circulation model, Biogeosciences, 6, 2099-2120, doi:10.5194/bg-6-2099-2009, 2009.

Vitousek, P. M., Fahey, T., Johnson, D. W., and Swift, M. J.: Element interactions in forest ecosystems - succession, allometry and input-output budgets, Biogeochem., 5, 7-34, 1988.

Walvoord, M. A., Phillips, F. M., Stonestrom, D. A., Evans, R. D., Hartsough, P. C., Newman, B. D., and Striegl, R. G.: A reservoir of nitrate beneath desert soils, Science, 302, 1021-1024, 2003.

Wang, Y. P. and Houlton, B. Z.: Nitrogen constraints on terrestrial carbon uptake: Implications for the global carbon-climate feedback, Geophys. Res. Lett., 36, 13-17, 2009.

Wania, R., Ross, I., and Prentice, I. C.: Integrating peatlands and permafrost into a dynamic global vegetation model: II. Evaluation and sensitivity of vegetation and carbon cycle processes, Global Biogeochem. Cy., 23, GB3015, doi:10.1029/2008GB003413, 2009.

Weaver, A. J., Eby, M., Wiebe, E. C., Bitz, C. M., Duffy, P. B., Ewen, T. L., Fanning, A. F., Holland, M. M., MacFadyen, A., Matthews, H. D., Meissner, K. J., Saenko, O., Schmittner, A., Wang, H. X., and Yoshimori, M.: The UVic Earth System Climate Model: Model description, climatology, and applications to past, present and future climates, Atmos. Ocean, 39, 361-428, 2001.

Weber, S. L., Drijfhout, S. S., Abe-Ouchi, A., Crucifix, M., Eby, M., Ganopolski, A., Murakami, S., Otto-Bliesner, B., and Peltier, W. R.: The modern and glacial overturning circulation in the Atlantic ocean in PMIP coupled model simulations, Clim. Past, 3, 51-64, doi:10.5194/cp-3-51-2007, 2007.

White, M. A., Thornton, P. E., Running, S. W., and Nemani, R. R.: Parameterization and sensitivity analysis of the BIOME-BGC Terrestrial Ecosystem Model: Net primary production controls, Earth Interact., 4, 1-85, 2000.

$\mathrm{Xu}$-Ri and Prentice, I. C.: Terrestrial nitrogen cycle simulation with a dynamic global vegetation model, Glob. Change Biol., 14, 1745-1764, 2008.

Yang, X. J., Wittig, V., Jain, A. K., and Post, W.: Integration of nitrogen cycle dynamics into the Integrated Science Assessment Model for the study of terrestrial ecosystem responses to global change, Global Biogeochem. Cy., 23, 121-149, 2009.

Zaehle, S. and Dalmonech, D.: Carbon-nitrogen interactions on land at global scales: current understanding in modelling climate biosphere feedbacks, Curr. Opin. Environ. Sustain., 3, 311-320, 2011.

Zaehle, S. and Friend, A. D.: Carbon and nitrogen cycle dynamics in the O-CN land surface model: 1. Model description, site-scale evaluation, and sensitivity to parameter estimates, Global Biogeochem. Cy., 24, doi:10.1029/2009GB003521, 2010.

Zaehle, S., Friedlingstein, P., and Friend, A. D.: Terrestrial nitrogen feedbacks may accelerate future climate change, Geophys. Res. Lett., 37, 121-149, 2010a. 
Zaehle, S., Friend, A. D., Friedlingstein, P., Dentener, F., Peylin, P., and Schulz, M.: Carbon and nitrogen cycle dynamics in the O$\mathrm{CN}$ land surface model: 2 . Role of the nitrogen cycle in the historical terrestrial carbon balance, Global Biogeochem. Cy., 24, doi:10.1029/2009GB003522, 2010b.

Zickfeld, K., Eby, M., and Weaver, A. J.: Carbon-cycle feedbacks of changes in the Atlantic meridional overturning circulation under future atmospheric $\mathrm{CO}_{2}$, Global Biogeochem. Cy., 22, doi:10.1029/2007GB003118, 2008.
Zinke, P. J., Stangenberger, A. G., Post, W. M., Emanuel, W. R., and Olson, J. S.: Worldwide organic soil carbon and nitrogen data, Tech. Rep. ORNL/TM-8857, Oak Ridge National Laboratory, Oak Ridge, TN, USA, 1984. 